DOI: $10.20472 / E F C .2017 .007 .006$

\author{
JAN HANOUSEK \\ CERGE-EI, Czech Republic
}

EVZEN KOCENDA

Charles University, Institute of Economic Studies, Czech Republic

PAVLA VOZAROVA

Czech Technical University in Prague, Czech Republic

\title{
HORIZONTAL CROWDING-OUT VERSUS VERTICAL SYNERGIES UNDER THE MNE PRESENCE
}

\begin{abstract}
:
In this paper we provide a comprehensive analysis of the impact of the multinational enterprises (MNEs) and foreign direct investment (FDI) on domestic firms in Europe. We build on the theoretical model of Markusen and Venables (1999) and modify it to better reflect reality and to capture international industrial linkages. For empirical part we build a unique and large database that covers 30 European countries over 2001 - 2013. Rich data are combined from the Amadeus, UN Comtrade and $\mathrm{BACl}$ sources. Our results do not show evidence for a pure spillover effect when other channels are controlled for. However, on a more detailed level we show that MNE's presence significantly affects domestic firms both in terms of changing market structure and productivity improvements. On other hand, change in sourcing patterns often results in that domestic firms are crowded-out. However, those domestic firms, that are able to withstand this double competition, receive additional benefits stemming from their interaction with downstream MNEs in form of productivity spillovers. We also document existence of trade (export) spillovers for both upstream and downstream levels. Despite that impact of the MNEs presence is not unambiguous the existence of positive production and trade spillovers is overwhelming.
\end{abstract}

\section{Keywords:}

multinational enterprise (MNE); foreign direct investment (FDI); European firms; spillovers; international trade

JEL Classification: F23, F15, F21 


\section{Introduction}

Foreign direct investments (FDI) is an operation by which a multinational enterprise (MNE) acquires a control over a domestic firm in a host economy via no less that $10 \%$ of voting rights (OECD, 2008). This happens either by investing in an existing company (brownfield) or by founding a new subsidiary (greenfield) in the host country. The extent and duration of the MNEs' presence in host economies is highly relevant for policymakers as well as the MNEs and host country governments often try to attract FDI with substantial and costly economic incentives (Meyer, 2004). ${ }^{1}$ Such behaviour is underlined by a strong belief that MNEs, via FDI, bring substantial external benefits, part of which materialize mostly in a form of range of spillovers (Blomström et al., 2000; Görg and Strobl, 2001; Görg and Greenaway, 2004). The capacity for spillovers from MNEs comes from their multi-market presence - the MNEs serve as channels to provide information about and to access foreign markets, foreign firms and foreign technology (Aitken et al. 1997). Understandably, interactions among domestic firms and MNEs are complex because they entail various perspectives, scopes and levels of productiontrade links. However, the literature analyzing effects of MNEs on host economies is fragmented. In this paper we aim to provide a comprehensive empirical assessment of those interactions in Europe.

Fragmentation of the literature is understandably caused by different angles the authors take to analyze the issue. We review related literature in Section 2 but here we present a sketch of existing research approaches. First, researchers primarily analyze interactions among MNEs and domestic firms from a production perspective along with resulting productivity and technology spillovers (Bodman and Le, 2013). This is done either (i) at a horizontal intra-industry level where the MNEs and local firms are competitors within the same industry or (ii) as partners in the vertical chain of production in the inter-industry relationship (vertical linkage). In the vertical interaction, an MNE, as an upstream industry entity, provides intermediary goods for other firms in a host economy (forward linkage). Alternatively, as a downstream industry entity, an MNE uses intermediary goods provided by domestic firms (backward linkage).

Second, research accentuate the changes in market conditions the MNEs cause. The influence of MNEs is most often evidenced via their production activities, and their impact on local firms is assumed to materialize mainly along the line of production via productivity spillover (Görg and Strobl, 2001). In this respect, MNEs may also substantially change domestic market conditions in terms of increasing competition that prompts crowding-out of the domestic firms who are unable to withstand heightened competition. On other hand, changes in domestic market conditions might lead to increasing demand for intermediary goods that provides more room for able domestic firms.

Third, researchers stress the international dimension of the FDI presence - the goods

1 Therefore, it is an imperative to know if the MNE entry indeed has the desired impact that would warrant the costs - both for the governments, which decide whether to promote FDI or not, and for the MNEs, which need to know their bargaining power in negotiations over the conditions of investment (Dunning and Lundan, 2008; Jones, 2014). 
produced by the MNEs can be sold on a domestic market or exported. Consequently, the goods used by MNEs as inputs can be purchased domestically or imported. The MNEs export activity is often substantial and affects the extent of their links with domestic firms via spillover effect. Seminal works of Aitken et al (1997) and Greenaway et al. (2004) show that the presence of MNEs produces an export spillover - a positive externality that lowers costs of trade and helps to increase export activities of domestic firms. Export spillovers are much less researched than traditional productivity spillovers, though. Potential reasons lie in obstacles imposed by the data availability.

Multifaceted issue of the MNEs' impact on domestic firms (an host economies in general) then underlies variety of questions that motivate our analysis. How does the FDI shape inter-industry allocations on national and international level? Do MNEs purchase intermediary goods from domestic suppliers, or do they prefer to import them? Alternatively, do MNEs purchase these goods from other multinationals in the domestic downstream sector? And, once we control for the changing sourcing patterns, do we observe any productivity spillovers from MNEs towards their domestic suppliers? Finally, do we observe any export spillovers from the FDI towards domestic firms?

In our empirical analysis we aim to tackle the above topics in a comprehensive manner and use both the variation in industry production and the variation in international trade flows. This strategy allows us to investigate the impact of FDI on the host economy along both vertical axis (between industries) and horizontal axis (within industry) in greater detail than any of the existing empirical analyses. We can see whether not only the demand for intermediary goods rises, but we can also determine to what extent it is covered by domestic firms as opposed to imported goods. We thus assess with better precision what is the impact of FDI on local suppliers and this also allows us to derive important policy implications from our findings.

We cover the production-trade linkages in the 30 European countries over the period 2001-2013. Our detailed data are combined from the Amadeus, UN Comtrade and BACI databases and provide rich basis to effectively analyze the MNEs impact on local firms. We provide separate findings for Western and Eastern European countries, before and after the global financial crisis (GFC). This approach allows for assessment of potential difference between both groups as well as relatively calm and distress periods. Finally, such large geographical coverage allows us to effectively incorporate the effect of international industrial linkages. In short, we bring forth a detailed analysis of the sourcing and supplying patterns of the MNEs in Europe as well as their interaction with domestic competitors. In doing so we stress the upstream-downstream relations, i.e. links between producers of intermediary (upstream) and consumer (downstream) goods.

Our results do not show evidence for a pure spillover effect when other channels are controlled for. However, on a more detailed level we show that MNE's presence significantly affects domestic firms both in terms of changing market structure and productivity improvements. On other hand, change in sourcing patterns often results in that domestic firms are crowded-out. However, those domestic firms, that are able to 
withstand this double competition, receive additional benefits stemming from their interaction with downstream MNEs in form of productivity spillovers. We also document existence of trade (export) spillovers for both upstream and downstream levels. Despite that impact of the MNEs presence is not unambiguous the existence of positive production and trade spillovers is overwhelming.

The rest of the paper is structured in the following way. In Section 2 we review related literature. We describe the theoretical model, potential channels of the FDI effects and estimable econometric specifications in Section 3. Our extensive data and their compilation are described in Section 4. Results are brought forward in Section 5 separately for upstream and downstream analyses. In Section 6 we summarize and conclude on our findings.

\section{Literature review}

The literature on the MNE and FDI effects on domestic firms is enormous. For this we review only a small subset of the literature that id directly related to our analysis and provide relevant references to surveys and meta-analyses instead. There are two key dimensions of the FDl's impact that the related literature distinguishes and studies. The first one is the inter-industry relationship (also called vertical linkage) that characterizes interactions between an MNE and its customers (forward vertical linkage) or between an MNE and its suppliers (backward vertical linkage). The second one is the intraindustry (or horizontal) level, which concerns the interaction between MNEs and its local competitors within the same industry. Both on vertical and horizontal level, there are two main channels of interactions between the MNE and other firms in the economy: market structure and technological transfers (Blalock and Gertler, 2008). The entry of a highly efficient MNE changes significantly the competition environment and market conditions for domestic firms - increase of competition on horizontal level is potentially off-set by higher demand for intermediate goods on the vertical level; at the same time, domestic firms can potentially benefit from productivity spillovers, which are externalities created by the presence of MNE in the market (Meyer and Sinani, 2009). Researchers assume that technologically more advanced MNE represents a positive example which domestic firms can follow by copying new technologies, by hiring workers or managers that have had experience in the foreign company, and so on (Xu and Sheng, 2012).

Along the vertical axis, both the market structure change and the productivity spillovers given by the entry of a highly efficient MNE in the domestic market are described in the theoretical model of Markusen \& Venables (1999), who compare three different scenarios: 1) the goods in the domestic market are produced by domestic firms, 2) the goods are produced by MNEs operating in the domestic market and 3) the goods are imported from abroad. The conclusion of the authors is that whereas the second and the third scenario increase competition within industry and may thus threaten domestic firms, the second scenario also boosts the demand for intermediary goods across industries and may thus bring profit to domestic suppliers. In addition, the second scenario as opposed to the third one provides scope for productivity spillovers, assuming that these need a face-to-face interaction between the two parties (domestic 
firms and MNEs), a hypothesis also supported by Ethier (1986).

The Markusen \& Venables (1999) model has one significant drawback - it does not allow for imports of intermediary goods and so foreign subsidiaries have to source all their imports locally ${ }^{2}$. This assumption is not realistic: we know that FDI is closely related to inter-sectoral trade and vertical integration of production chain, as shown in theoretical models (e.g. Helpman, 1984) and documented by empirical work (see Lanz, 2011). In reality, the potential increase in demand for intermediary goods given by FDI inflow and related enhanced industrial activity (as predicted by Markusen \& Venables, 1999) is not always covered by domestic firms. MNEs can prefer to purchase the intermediary goods from abroad, and so the overall impact on domestic suppliers can be finally even negative.

It is usually not tested empirically whether foreign subsidiaries use domestic suppliers more or less intensively than domestic firms, but the general perception is that the share of domestically sourced goods is lower in case of foreign subsidiaries (Jordaan, 2011). There is some mixed evidence on this issue, which seems to depend on the country in question: whereas Jordaan (2011) finds in case of Mexico that foreign subsidiaries use local suppliers to the same extent as domestic firms, Javorcik \& Spatareanu (2005) find the opposite in case of Czech Republic and Lithuania. Whereas Javorcik \& Spatareanu (2005) claim that the insufficient quality of locally supplied intermediary goods is the main reason for which MNEs source from abroad, Jindra (2009) explains that the choice of local or foreign supplier depends also to a great extent on the type of foreign subsidiary.

In any case, whether links between MNEs' subsidiaries and local suppliers are established or not is a question of crucial importance, because only then potential productivity spillovers can materialize. These spillovers may improve further the efficiency of domestic firms and amplify the positive effect of increasing demand, and they are thus a highly desired externality emanating from MNEs' activity (see UNCTAD, 2001). As such, they are widely studied in current empirical literature related to FDI (Havránek and Iršová, 2012).

Unfortunately, the empirical literature fails somehow to reflect the issue of spillovers related to sourcing patterns of MNEs in their complexity. First, empirical analyses are usually focused on productivity spillovers only (Görg and Strobl, 2001) and omit the issue of changing market structure and increasing demand (Peretto, 2002). Smeets (2008) revises empirical evidence of the impact of FDI and clearly illustrates that the majority of studies published in this field concern technological transfers. An even more detailed survey of these papers can be found in Hanousek, Kocenda \& Maurel (2011), who show that horizontal spillovers are often found to be insignificant or negative, whereas vertical spillovers are found to be significant and rather positive. However, this

\footnotetext{
${ }^{2}$ Markusen \& Venables (1999) model is one of the two theoretical models that study the impact of MNEs on the local suppliers of intermediary goods. The second model by Rodriguez (1996) is not very stuitable for our study since it is tailored to the situation in underdeveloped countries. In this model, domestic firms and MNEs are producing different types of good because there are not enough suppliers of sophisticated intermediary goods in the country and domestic firms cannot import them. We do not think such assumptions are realistic in EU countries.
} 
evidence is very mixed and depends usually on the country and time period over which the analysis was performed. Many of the papers are limited by their geographical and industrial scope, focusing on one country and/or one industry only (see Dries, 2004), which gives certainly an interesting insight, but which is hard to further generalize.

A second important drawback of existing empirical literature is the fact that it usually ignores, or at least underestimates, the role of international trade and its interaction with FDI activities. Importing intermediary goods by MNEs suggests that FDI and trade flows might be closely linked. Keller (2010) shows that although there are studies of the impact of international trade as well as of the impact of FDI, no study focuses on both aspects at the same time with the same intensity. For example, Jurajda \& Stančík (2012) perform their analysis of horizontal and vertical FDI spillovers separately for import oriented and export oriented industries, and Lesher \& Miroudot (2008) include trade variables on country level in their sectoral regressions; however, these approaches, even if they confirm that the international trade flows matter for the impact of FDI, still do not exploit fully their variation on sectoral level. Hence, there is a large gap in the existing empirical literature, given probably by the fact that it is not very easy to link data on firms or industries with data on international trade, at least not at a sufficiently disaggregated level. Traded goods are classified under different coding than the one used for classification of industries, and no direct correspondence table is available.

\section{Methodology}

\section{Model and theoretical predictions}

In this paper, our aim is to analyze whether the FDI inflow increases sales of domestic producers of intermediary goods. These sales can take form of intermediary goods sold in the domestic market or those that are exported. In this way we are able to analyze not only classical productivity spillovers but also more elusive export spillovers.

We build on the theoretical model of Markusen \& Venables (1999) and modify it to better reflect reality and to capture international industrial linkages. In the model, the authors show that under certain circumstances, the increased activity of multinational firms in the downstream sector should increase the demand for intermediary goods. They assume that the MNEs are more efficient than domestic firms, which increases the production in the sector of consumer goods, and moreover, that they use intermediary goods more intensively, which drives the demand for these goods up.

To represent this idea formally, we need to introduce the notation that will be used throughout our paper. In Markusen \& Venables (1999) model, two sectors are defined: sector of intermediary goods and sector of consumer goods. In reality, basically all sectors of the economy can be considered as producing both intermediary and consumer goods, and therefore such distinction would not be practical here. Hence, we will denote sectors as downstream and upstream sectors, where downstream sectors use intermediary goods provided by upstream sectors. Obviously, all industries can play downstream and upstream role: as upstream industries, they provide intermediary goods for other sectors, as downstream industries, they use intermediary goods 
provided by other sectors.

Formally, Markusen \& Venables (1999) assume the sales by upstream sector (Sales ${ }^{U p}$ ) to be a function of FDI in the downstream sector $\left(F D I^{\text {Down }}\right)$ : Sales $^{U p}=f\left(F D I^{\text {Down }}\right)$, with $\frac{d \text { Sales }^{U p}}{d F D I^{D o w n}}>0$. To answer our research question, this prediction of the theoretical model will be modified in two ways. First, it should not be forgotten that the model is derived under the assumption that the total demand for the goods produced in the downstream sector is fixed and that there is no trade in intermediary goods. Neither of this has to be true. The demand for consumer goods produced by downstream sector varies over time, which would affect also the demand for intermediary goods produced by upstream sector. Also, part of the intermediary goods can be imported or exported. It is therefore more realistic to see the sales of intermediary goods produced by upstream sector $\left(\right.$ Sales $\left.^{U p}\right)$ as a function of FDI in the downstream sector ( $\left.F D I^{D o w n}\right)$, sales of consumer goods by downstream sector (Sales ${ }^{\text {Down }}$ ), imports of intermediary goods (Imports ${ }^{U p}$ ) and exports of intermediary goods (Exports $\left.{ }^{U p}\right)$ : $\quad$ Sales ${ }^{U p}=$ $f\left(F D I^{\text {Down }}\right.$, Sales $^{\text {Down }}$, Imports ${ }^{U p}$, Exports $\left.^{U p}\right)$. Moreover, according to models described in Section 2, it has to be expected that the production of consumer goods as well as imports and exports of intermediary goods are also a function of FDI in the downstream sector, which leads to the following model:

$$
\begin{gathered}
\text { Sales }^{U p}= \\
f\left(F D I^{\text {Down }}, \text { Sales }^{\text {Down }}\left(F D I^{\text {Down }}\right), \text { Imports }^{U p}\left(F D I^{\text {Down }}\right), \text { Exports }^{U p}\left(F D I^{\text {Down }}\right)\right) .
\end{gathered}
$$

Second, in Markusen \& Venables (1999) model, intermediary goods are produced by domestic firms only, whereas in reality, MNEs can enter also the upstream sector. We want to estimate the impact of downstream FDI on sales of domestically produced intermediate goods, which is only a part of total sales. When we denote the domestically produced intermediate goods DSales ${ }^{U p}$ and those produced by MNEs operating in the intermediate goods sector $F_{S a l e s}{ }^{U p}$, we can write

$$
\begin{gathered}
\text { Sales }^{U p}=\text { DSales }^{U p} \cdot\left(\frac{\text { Sales }^{U p}}{\text { DSales }^{U p}}\right)=f\left(\text { FDI }^{\text {Down }} \text {,Sales }^{\text {Down }}, \text { Imports }^{U p}, \text { Exports }^{U p}\right) \\
\text { DSales }^{U p}=\frac{\text { DSales }^{U p}}{\text { Sales }^{U p}} \cdot f\left(F D I^{\text {Down }}, \text { Sales }^{\text {Down }}, \text { Imports }^{U p}, \text { Exports }^{U p}\right) .
\end{gathered}
$$

This implies that

$$
\begin{aligned}
& \frac{d D \text { Sales }^{U p}}{d F D I^{\text {Down }}}=\frac{{d \text { Dsales }^{U p}}^{\text {Sales }}{ }^{U p}}{d F D I^{\text {Down }}} \cdot f\left(F^{\text {DDI Iown }}{ }^{\text {Dales }}{ }^{\text {Down }}, \text { Imports }^{U p}, \text { Exports }^{U p}\right) \\
& +\frac{\text { DSales }^{U p}}{\text { Sales }^{U p}} \cdot \frac{d f\left(F D I^{\text {Down }}, \text { Sales }^{\text {Down }}, \text { Imports }^{U p}, \text { Exports }^{U p}\right)}{d F D I^{\text {Down }}} \text {, }
\end{aligned}
$$

where 


$$
\begin{aligned}
& \frac{d f\left(F D I^{\text {Down }}, \text { Sales }^{\text {Down }}, \text { Imports }^{U p}, \text { Exports }^{U p}\right)}{d F D I^{\text {Down }}} \\
&=\frac{\partial f\left(F D I^{\text {Down }}, \text { Sales }^{\text {Down }}, \text { Imports }^{U p}, \text { Exports }^{U p}\right)}{\partial F I^{\text {Down }}} \\
&+\frac{\partial f\left(F D I^{\text {Down }}, \text { Sales }^{\text {Down }}, \text { Imports }^{U p}, \text { Exports }^{U p}\right)}{\partial \text { Sales }^{\text {Down }}} \cdot \frac{\text { Sales }^{\text {Down }}}{d F D I^{\text {Down }}} \\
&+\frac{\partial f\left(F D I^{\text {Down }}, \text { Sales }^{\text {Down }}, \text { Imports }^{U p}, \text { Exports }^{U p}\right)}{\partial \text { Imports }^{U p}} \cdot \frac{\text { IImports }^{U p}}{d F D I^{\text {Down }}} \\
&+\frac{\partial f\left(F D I^{\text {Down }}, \text { Sales }^{\text {Down }}, \text { Imports }^{U p}, \text { Exports }^{U p}\right)}{\partial \text { Exports }^{U p}} \cdot \frac{\text { Exports }^{U p}}{d F D I^{\text {Down }}} .
\end{aligned}
$$

After substituting back $f\left(F D I^{\text {Down }}\right.$, Sales ${ }^{\text {Down }}$, Imports $^{U p}$, Exports $\left.^{U p}\right)=$ Sales $^{U p}$, we obtain:

$$
\begin{aligned}
& \frac{d_{\text {DSales }}^{U p}}{d F D I^{\text {Down }}}=\frac{\text { DDSales }^{U p} / \text { Sales }^{U p}}{d F D I^{\text {Down }}} \cdot \text { Sales }^{U p}+\frac{\text { DSales }^{U p}}{\text { Sales }^{U p}} \\
& \cdot\left(\frac{\text { SAales }^{U p}}{\partial F I^{\text {Down }}}+\frac{\text { SSales }^{U p}}{\partial \text { Sales }^{\text {Down }}} \cdot \frac{\text { SSales }^{\text {Down }}}{d F D I^{\text {Down }}}+\frac{\text { SSales }^{U p}}{\text { Imports }^{U p}} \cdot \frac{\text { dImports }^{U p}}{\text { dFDI }^{\text {Down }}}\right. \\
& \left.+\frac{\text { SSales }^{U p}}{\text { Exports }^{U p}} \cdot \frac{d \text { Exports }^{U p}}{d F D I^{\text {Down }}}\right) \text {. }
\end{aligned}
$$

Such expression is rather complex, but it can be schematized in the following way:

$$
\frac{\text { dDSales }^{U p}}{\text { dFDI }^{\text {Down }}}=\Delta_{1}+\Delta_{2}+\Delta_{3}+\Delta_{4}+\Delta_{5}
$$

where $\Delta$ 's stand for five different channels through which downstream FDI can influence sales of intermediate goods by domestic firms in the upstream sector. Their economic interpretation is as follows:

- $\quad \Delta_{1}=\frac{\text { dDSales }^{U p} / \text { Sales }^{U p}}{d F D I^{D o w n}} \cdot$ Sales $^{U p}$ captures the impact of downstream FDI through the changing proportion of intermediary goods supplied by domestic producers, as compared to multinational firms operating in the country within the upstream sector. We may expect this impact to be negative at least for two reasons. First, according to Javorcik \& Spatareanu (2005), especially in less developed countries domestic suppliers often do not meet the standard required by MNEs in the downstream sector, which then prefer to source from foreign suppliers. Further, according to Cohen (2007), it is very likely that these foreign suppliers will be really present in the country through FDI in the upstream sector, as presence of MNEs in one sector often attracts further FDI in related sectors. - $\quad \Delta_{2}=\frac{\text { SSales }^{U p}}{\text { Sales }^{U p}} \cdot \frac{\partial \text { Sales }^{U p}}{\partial F D I^{D o w n}}$ captures the direct impact of downstream FDI on sales of intermediary goods, which can be interpreted as the pure spillover effect. Based on empirical studies such as Stančík (2010) or Gorodnichenko et al (2015), we can expect this impact to be positive: MNEs have motivation to help their local suppliers to improve.

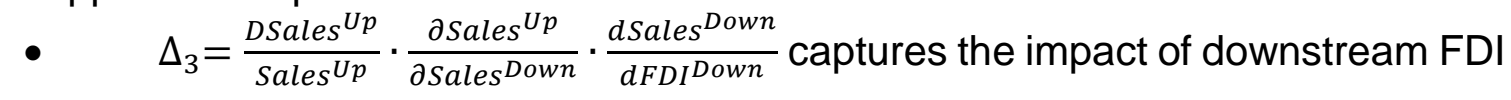


through sales of intermediary goods that is given by 1) change in sales by downstream industry driven by FDI (the term $\frac{d \text { Sales }^{\text {Down }}}{d F D I^{\text {Down }}}$ ) and 2) change in the sales of intermediary goods given by change in sales by downstream industry (the term $\frac{\text { SSales }^{U p}}{\left.\partial \text { sales }^{D o w n}\right)}$. The first component of this impact is supposed to be positive, since many studies, such as e.g. Jurajda \& Stančík (2012), predict that FDI inflow is correlated with productivity in the given sector. The second component of the impact is naturally supposed to be positive as well - increasing production in downstream sector should go in hand with increasing production of intermediary goods that serve as inputs. It has to be noted that quantitatively, this relation may depend on the level of FDI in the downstream sector: for example, Markusen \& Venables (1999) suppose that MNEs may use intermediary goods more intensively than domestic firms. Studies that deal with horizontal spillovers (see e.g. Hanousek, Kocenda \& Maurel, 2010) bring opposite arguments - more efficient MNEs may be able to produce more output with less input as compared to domestic firms. Hence, even if the production in downstream sector increases due to FDI, the positive effect on demand for intermediary goods may be offset by the capacity of MNEs to save on inputs. For this reason, the effect $\Delta_{3}$ captures both the potential increase of production in the downstream sector and the consecutive increase of demand for intermediary goods, but also the correction of such increase given by the intensity in which MNEs source the inputs.

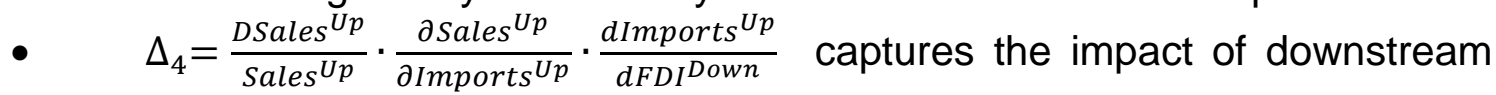
FDI on sales of intermediary goods that is given by 1) change in imports driven by downstream FDI (the term $\frac{\text { dImports }^{U p}}{\text { fFDI }^{\text {Down }} \text { ) }}$ and 2) change in sales of intermediate

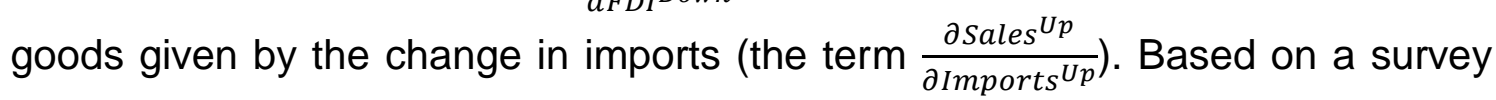
described in Javorcik \& Spatareanu (2005), the first component of this impact is supposed to be positive, because MNEs are more likely to import their inputs from abroad than domestic firms. The second component of the impact is clearly negative if we assume that domestic and imported intermediate goods are substitutes and their suppliers compete. For this reason, the overall effect $\Delta_{4}$ is supposed to be negative.

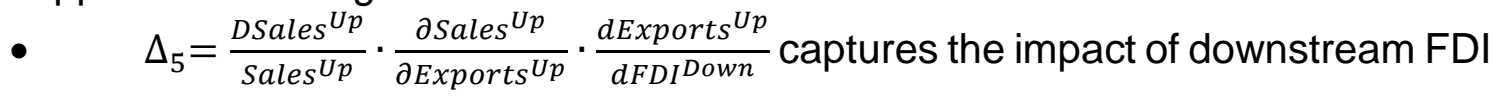
on sales of intermediary goods that is given by 1 ) change in exports driven by downstream FDI (the term $\frac{d E x p o r t s}{d F D I^{D o w n}}$ ) and 2) change in sales of intermediary goods given by the change in exports (the term $\frac{\partial \text { sales }^{U p}}{\partial \text { Exports }^{U p}}$ ). Thus, this term captures the so-called export spillovers but exhibits some difficulties in terms of its interpretation. Both components can be positive or negative based on circumstances. All depends on whether local producers of intermediary goods (domestic or with foreign owners) benefit from the presence of MNEs in the downstream sector and become more efficient and thus also more likely to export. Further, it also depends on whether the firms exploit this hypothetical potential to 
export and whether their exports are proportional or not to domestic sales. And finally, exports may be even reduced if goods that were so far exported are now supplied to incoming MNEs. Hence, the overall impact given by $\Delta_{5}$ is hard to predict. Hovever, this part of the model enables to detect export spillovers in a more direct way that it was done in earlier literature.

\section{Econometric specification for the upstream sector}

The main purpose of our analysis is to describe how FDI in the downstream sector influences the sales of domestic suppliers in the upstream sector. In order to assess whether the above impact is in line with theoretical predictions presented in Section 3.1. we propose a semi-logarithmic specification (2) that contains all variables of interest; we are also able to interpret most of the coefficients as elasticities. We keep in mind that there are five main channels of the downstream FDI impact that we need to capture in our specification: the pure spillover effect, impact through changing upstream FDI, impact through changing imports, impact through changing exports and impact through changing sales in the upstream industry,

We observe industries over time and hence the natural structure of our data is a panel. This structure is also in line with Görg and Strobl (2001) and Aitken and Harrison (1999) who argue that panel data analysis is a more appropriate method assess productivity spillovers. Our basic specification is as follows:

$$
\begin{aligned}
\ln \left(\text { DSales }_{i t}^{U p}\right)= & \beta_{0}+\beta_{1} F D I_{i t}^{\text {Down }}+\beta_{2} F D I_{i t}^{U p} F D I_{i t}^{\text {Down }} \\
+ & \beta_{3} \ln \left(\text { Imports }_{i t}^{U p}\right)+\beta_{4} \ln \left(\text { Imports }_{i t}^{U p}\right) \cdot F D I_{i t}^{\text {Down }}+ \\
+ & \beta_{5} \ln \left(\text { Exports }_{i t}^{U p}\right)+\beta_{6} \ln \left(\text { Exports }_{i t}^{U p}\right) \cdot F D I_{i t}^{\text {Down }}+ \\
& +\beta_{7} \ln \left(\text { Sales }_{i t}^{\text {Down }}\right)+\beta_{8} \ln \left(\text { FSales }_{i t}^{U p}\right)+\beta_{9} n o F D I_{i t}^{U p} \\
& +\beta_{10} \ln \left(\text { Exports }_{i t}^{\text {Down }}\right)+\beta_{11} \ln \left(\text { Imports }_{i t}^{\text {Down }}\right)+\vartheta_{i t}
\end{aligned}
$$

where all variables are denoted in the same way as in Section 3.1. Index $t$ denotes time, index $i$ denotes a specific industry in a specific country and $\vartheta_{i t}$ is the error term that in our panel specification takes the following form: the structure of the error term is $\vartheta_{i t}=$ $\alpha_{i}+\eta_{t}+\varepsilon_{i t}$, where $\alpha_{i}$ is the country-industry specific fixed effect, $\eta_{t}$ is the time specific fixed effect and $\varepsilon_{i t}$ is the idiosyncratic error term.

The main variable of interest is the presence of multinational firms in the downstream industry (FDIDown.), and its interaction terms. The control variables are chosen in line with the above presented theoretical reasoning. The industry, country and countryindustry specific fixed effects allow to control for time-invariant industry and country characteristics and time specific fixed effects control for aggregate shocks to the economy due to business cycles.

The parameter $\beta_{1}$ represents the pure spillover effect, since all other channels through 
which downstream FDI influences the upstream sector of intermediary goods (according to theoretical predictions) are controlled for.

The parameter $\beta_{2}$ captures the effect on sales of intermediary goods driven by the potential preference of the foreign firms coming into the downstream sector to source their supplies from other multinational firms rather than from domestic suppliers. Its interpretation is based on the interaction between the level of FDI in the upstream sector and the level of FDI in the downstream sector. Our prior is that if $\beta_{1}$ is negative, it means that foreign firms in the downstream sector prefer to source their inputs from multinational suppliers, which decreases the sales of domestic producers of intermediary goods.

The parameter $\beta_{4}$ describes the effect on sales of intermediary goods driven by the fact that foreign firms coming into the downstream sector may prefer to import their supplies rather than purchase them from domestic suppliers.

The parameter $\beta_{6}$ represents the influence that downstream FDI has on upstream sales by affecting exports from the upstream industry.

The parameters $\beta_{3}$ and $\beta_{8}$ capture the influence of imports and foreign sales, respectively. These are so-called pull factors and represent a direct competition within the industry. The parameters $\beta_{5}$ and $\beta_{7}$, on the other hand, capture the influence of exports and sales of the downstream industry goods, respectively. These are so-called push factors and represent potential changes in demand.

The parameter $\beta_{9}$ corresponds to a dummy noFD/Up, which is equal to 1 when there is no FDI in the upstream sector and 0 otherwise. This approach will allows us to increase the number of our observation by including those sectors with negligible foreign presence in the upstream sector (for which $F S a l e s \cup p=0$ ). The coefficient on this dummy variable is the mean effect of missing foreign firms in the industry - this could have different reasons, ranging from local regulations/restrictions to low attractiveness of the underlying sector.

The parameters $\beta_{10}$ and $\beta_{11}$ allow us to control for the effect of exports and imports in the downstream sector and capture thus changes in demand for consumer goods as well as changes in competition within the sector of these goods, which may have additional impact on the upstream sector.

\section{Econometric specification for the downstream sector}

The treatment of the linkages from the perspective of the upstream sector represents the key objective of our analysis. As a complement to the main research question we also analyze the impact of upstream FDI on sales by domestic firms in downstream sector.

The reason for including this complementary analysis is to see whether the suppliercustomer vertical relations between industries are affected by FDI also in the opposite direction than the one presented in the previous sections of this paper. In other words, so far we asked how domestic firms are affected by MNEs among their customers, now 
we ask how they are affected by FDI activity in the sector from which they source their supplies. Such perspective contributes to a better understanding of sourcing patterns affected by FDI. There is no theoretical model on which we could rely here and but in principle, we are estimating the links that are complementary for the estimated links of the upstream sector.

Hence, our complementary specification captures the impact of downstream FDI on sales by domestic firms in upstream sector in the following form:

$$
\begin{aligned}
\ln \left(\text { DSales }_{i t}^{\text {Down }}\right)= & \beta_{0}+\beta_{1} F D I_{i t}^{U p}+\beta_{2} F D I_{i t}^{\text {Down }} F D I_{i t}^{U p} \\
+ & \beta_{3} \ln \left(\text { Imports }_{i t}^{\text {Down }}\right)+\beta_{4} \ln \left(\text { Imports }_{i t}^{\text {Down }}\right) \cdot F D I_{i t}^{U p}+ \\
+ & \beta_{5} \ln \left(\text { Exports }_{i t}^{\text {Down }}\right)+\beta_{6} \ln \left(\text { Exports }_{i t}^{\text {Down }}\right) \cdot F D I_{i t}^{U p}+ \\
+ & \beta_{7} \ln \left(\text { Sales }_{i t}^{U p}\right)+\beta_{8} \ln \left(\text { FSales }_{i t}^{\text {Down }}\right)+\beta_{9} n o F D I_{i t}^{\text {Down }}+ \\
& \quad+\beta_{10} \ln \left(\text { Exports }_{i t}^{U p}\right)+\beta_{11} \ln \left(\text { Imports }_{i t}^{U p}\right)+\vartheta_{i t} .
\end{aligned}
$$

All variables in specification (3) are denoted in the same way as in the model presented in Section 3.1 and all indices and the structure of the error term is same as in specification (2) in Section 3.2.

The main variable of interest in (3) is $F D / U p$, the presence of multinational firms in the upstream industry, and its interaction terms. We ask here how upstream FDI affects through different channels the sales of domestic firms in the downstream industry. The reason for including this complementary analysis is to see whether the suppliercustomer vertical relations between industries are affected by FDI also in the opposite direction than the one presented in the previous sections of this paper. In other words, so far we asked how domestic firms are affected by MNEs among their customers, now we ask how they are affected by FDI activity in the sector from which they source their supplies. Such perspective contributes to a better understanding of sourcing patterns affected by FDI. In theory, there is no reason why spillover effects and effects of changing demand and competition should not be present also along this direction.

In the specification (3), the parameter $\beta_{1}$ represents the pure spillover effect stemming from multinational firms in the supplying intermediary goods industries. The parameter $\beta_{2}$ relativizes this spillover effect - it allows for different intensity (and even sign) of the spillover on domestic producers of consumer goods in industries with higher share or MNEs, in which the effect of upstream FDI can be different if MNEs tend to cooperate between sectors.

The parameters $\beta_{3}$ and $\beta_{8}$ capture the influence of imports and foreign sales, representing thus direct competition within the industry. The parameter $\beta_{4}$ relativizes the competition given by imports in industries that use multinational suppliers more 
intensively. The parameters $\beta_{5}$ and $\beta_{7}$ capture the influence of exports and sales of the upstream goods, representing thus potential changes in demand. In case of exports, this influence is relativized by the parameter $\beta_{6}$ for industries that use multinational suppliers more intensively.

The parameter $\beta_{9}$ corresponds to a dummy noFDIDown, which is equal to 1 when there is no FDI in the downstream sector and 0 otherwise. Similarly as in the upstream model, using this dummy we will increase the number of observations. Correspondingly, the coefficient on the dummy noFDIDown contains the mean effect on missing foreign presence in the industrial sector.

The parameters $\beta_{10}$ and $\beta_{11}$ allow us to control for the effect of exports and imports in the upstream sector and capture thus changes in demand for intermediate goods as well as changes in competition within the sector of these goods, which may have additional impact on the downstream sector.

\section{Data description}

\section{Geographic and time coverage}

Our analysis covers 30 European countries and spans over the time period 2001 - 2013. The European countries are further divided into two groups that are for the convenience of exposition labelled as Western and Eastern countries. The Western countries are (in alphabetical order): Austria, Belgium, Denmark, Finland, France, Germany, Greece, Iceland, Ireland, Italy, Netherlands, Norway, Portugal, Spain, Sweden, Switzerland and United Kingdom. Hence, the Western countries include the Eurostat-coded EU15 plus Iceland, Norway and Switzerland. The Eastern countries are the Eurostat-coded EA27 countries that joined the European Union in 2004, 2010 and 2015. Hence, the Eastern countries include: Bulgaria, Cyprus, Czech Republic, Estonia, Croatia, Hungary, Lithuania, Latvia, Malta, Poland, Romania, Slovenia and Slovakia. The analysis is performed for both groups separately to see the differences between fully developed countries and those who had undergone the transition period, EU-accession-screening or both. The comparison of these two groups allows us to draw further conclusions about the studied issue.

\section{Data sources}

We use the Amadeus database to obtain the level of sales and FDI presence in given industries. This database contains information about firms operating in the chosen countries: their performance, their financial and organizational characteristics, their industry classification expressed by the three-digit NACE code (Rev. 1.1 or, after 2008 Rev. 2), and their ownership structure allowing to differentiate between domestic and foreign owners. We link this database with information from the UN COMTRADE, respectively from the $\mathrm{BACl}$ database. ${ }^{3} \mathrm{BACl}$ provides information on bilateral values and quantities of exports at the Harmonized System (HS) 6-digit product

${ }^{3} \mathrm{BACl}$ dataset is developed by the CEPII (Gauilier and Zignago, 2010); it is constructed using COMTRADE data and reconciles the declarations of the exporter and the importer. It extends considerably the number of countries, as well as convenience of use. 
disaggregation. Using correspondence tables, we have therefore detailed information on international trade flows disaggregated to the four- and five-digits SITC level (Rev. 3).

Finally, we use the EUROSTAT database to obtain detailed input-output tables of industries (at two-digits NACE, Rev. 1.1 or Rev. 2) constructed separately for groups of Western and Eastern countries. The following subsection provides details of data linkages and variable definitions.

\section{Data harmonization}

Since our main research question concerns the interaction between upstream and downstream industries both in terms of production and trade, we first need to establish links between these industries. For this purpose, we use the input-output (I-O) tables from the EUROSTAT database for years 2001-20134. Specifically, we use aggregated I-O tables for EU2 $7^{5}$ or EA $17^{6}$ countries, since they are available from EUROSTAT for the whole period under research. These tables allow us to construct a matrix with coefficients representing the share of output supplied to different downstream industries, which will be used for definition of variables used in our analysis in a way that we will describe later.

The I-O tables are available in two different NACE revisions - revision 1.1 for years 2001-2007 and revision 2 for years 2008-2013. The same division holds for NACE classification provided by Amadeus. We decided to transform all our data to be coded as under NACE revision 1.1, which implied the use of correspondence tables provided by Eurostat. ${ }^{8}$ Note that the $\mathrm{I}-\mathrm{O}$ tables are available at the aggregated two-digit NACE level, which is the reason why we set this aggregation as the baseline industry level of our analysis. This means that we aggregate all data from Amadeus and $\mathrm{BACl}$ databases to this level.

The only technical problem is that the BACI database is coded under SITC classification system, and so we needed first to harmonize the SITC Rev. 3 codes with the NACE Rev. 1.1 codes and to transform the trade database into the NACE coding. Unfortunately, there is no direct correspondence between the NACE and SITC coding systems, and hence, for harmonizing the $\mathrm{BACl}$ trade data with the rest of our dataset, we created manually a link between them using other coding systems for which the correspondence tables are available from the United Nations Statistics Division. ${ }^{9}$ Finally, we linked the data using the following set of transformations:

\footnotetext{
4 These are naio_agg_60 and naio_agg_60_r2 files accessible from http://ec.europa.eu/eurostat/web/esa-supplyuse-input-

tables/data/database?p $p$ id=NavTreeportletprod WAR NavTreeportletprod INSTANCE P21JIHPgZkWW\&p p I ifecycle $=0 \& p$ state $=$ normal $\& p$ mode $=$ view $\& p$ col $i d=$ column $-2 \& p \quad p$ col count $=3$

5 The whole European Union - this table is used for Eastern countries.

${ }^{6}$ Euro area countries - this table is used for Western countries.

7 Precisely speaking, tables for years 2012 and 2013 are not available, for these years, we use tables for 2011.

8 These correspondence tables display $n$-to- $n$ relations, and hence we collapse several industries together, following the structure of Eurostat I-O tables.

${ }^{9}$ http: //unstats.un.org/unsd/cr/registry/regot.asp?Lg=1
} 
SITC Rev. $3 \rightarrow$ CPC Ver. $2 \rightarrow$ ISIC Rev. $4 \rightarrow$ ISIC Rev. $3 \rightarrow$ NACE Rev. 1.1.

This link was prepared using VBA programming, however the final tuning and verification of all correspondences (in a table of some 4000 rows) was done manually. Further information about these technical issues can be provided upon request. The final result is schematically presented in the Appendix, where we display the lists of NACE Rev. 1.1 industries and SITC Rev. 4 types of goods aggregated at two-digit level, as well as a table representing what SITC types of goods fall into what NACE Rev. 1.1 categories. ${ }^{10}$

Data from Amadeus are transformed to be measured in millions of euros, imports and exports are measured in thousands of US dollars; in the main specification we use logarithmic transformation and ratios, hence the interpretation of our empirical models is independent of currencies and units used.

\section{Definition of variables and resulting dataset}

In Section 3.1, we explained the mechanisms through which FDI in the sector of consumer goods (downstream sector) influences sales in the sector of intermediary goods (upstream sector), and in sections 3.2 and 3.3, we presented the regression specifications that we use for the analysis of downstream and upstream sectors, respectively. This division between consumer and intermediary goods is suitable for the presentation of the theoretical model, but in reality, the industry structure is much more complex and each sector can produce goods that are used either as intermediaries for another sector or as final goods. Therefore, in our analysis we consider all sectors to be potential producers of intermediary goods and we link them to their corresponding downstream sectors to which they supply.

One of the most important tools for this construction is the input-output matrix $\boldsymbol{A}_{t}$, which is constructed from the Eurostat input-output tables. The row elements of this matrix represent shares with which the given upstream industry supplies to all its upstream industries other than the given industry itself. Since we do not want to include withinindustry sourcing patterns, the diagonal of this matrix is by definition equal to zero. Such use of the input-output tables is in line with the standard approach set by Javorcik (2004). The matrix $\boldsymbol{A}_{t}$ is used for the construction of variables in the downstream analysis (Section 4.2), while in the upstream analysis (Section 4.3) we use the transpose of $\boldsymbol{A}_{t}$.

Another crucial element of our data construction is the definition of a foreign firm that determines the measure of FDI within each sector. This definition is based on the principle of control (La Porta et al. 1999). By a foreign firm we understand a foreign controlled firm, i.e., the firm in which the main foreign owner controls more than the sum of remaining ownership rights of all known shareholders. This definition of control is

\footnotetext{
10 Let us note that correspondence provided in the Appendix depicts the main associations since we were linking SITC goods at five or four digits level. In the table presented in the Appendix, it may seem that several SITC goods fall into more than one NACE categories, but this is due only to the fact that goods with the same SITC two-digits representation fall into different NACE industries when considered at more disaggregated level.
} 
standard and circumvents the issue of dispersed ownership that was shown to play no role with respect to firms' efficiency specifically in the European context (Hanousek et al., 2015)

The construction of all key variables that characterize potential effects of the FDI in the upstream and downstream sectors used in our regressions is explained in the Appendix Tables $A 1$ and $A 2$, respectively. Both tables also contain precise information on the sources and units used.

By combining and aggregating all available information on economic activity of firms, their ownership structure, links between industries and trade flows, we obtain a unique dataset of approximatively 5000 observations. The dataset has a structure of a panel of industries in the European countries over the period 2001 - 2013. Descriptive statistics of all variables are provided in Table 1.

\section{Results}

\section{Results for upstream analysis}

In this section, we present results of our main specification described in Section 3.2, i.e., the analysis of the upstream industry, in which we study how this industry is affected by FDI in the corresponding downstream industry, with special focus on changes in sourcing patterns.

Our key results for the upstream analysis are based on specification (2). Recall that the structure of the error term in specification (2) is $\vartheta_{i t}=\alpha_{i}+\eta_{t}+\varepsilon_{i t}$, where $\alpha_{i}$ captures interacting country-industry specific fixed effect, $\eta_{t}$ is the time specific fixed effect and $\varepsilon_{i t}$ is the idiosyncratic error term. In this case, the interacting country-industry specific fixed effect denotes specific industry sector $i$ in an individual country from within Western or Eastern countries. Thus, in this setting the countries are assumed to behave as a common market within the specific industry.

The panel regression estimates are presented in Tables 2 and 3 for Western and Eastern European countries, respectively. Each table has three column sections: in the first one, the results originate from the estimation performed over the whole time period 2001-2013, in the second one, only the pre-financial crisis years are taken into account, and the third one focuses on the post-crisis period.

As an extension and robustness check, we also present results of the estimation that allows for separate industry, individual country and time specific fixed effects. In this case, the structure of the error term $\left(\vartheta_{i t}\right)$ in specification (2) is sligthly modified as $\vartheta_{i t}=$ $\theta_{i}+\delta_{j}+\eta_{t}+\varepsilon_{i t}$, where $\theta_{i}$ is the industry specific fixed effect, $\delta_{j}$ is an individual country specific fixed effect, $\eta_{t}$ is the time specific fixed effect and $\varepsilon_{i t}$ is the idiosyncratic error term. In this modification, individual countries from within Western or Eastern countries are assumed to behave as separate markets. We present the results for this specification in Appendix Tables A3 and A4 for Western and Eastern European countries, respectively.

As our specification (2) is quite rich and we report results separately for two groups of 
countries based on two sets of estimates. Hence, we facilitate presentation and interpretation of our results in the following text by including coefficient's symbols and table numbers. Our results below are commented on based on the five main channels through which FDI affects sales in the downstream industry (see Section 3.1).

First, we do not find evidence for a pure spillover effect $\left(\beta_{1}\right)$ due to the lack of statistical significance for both Western and Eastern countries (Tables 2 and 3). In our modified estimation, no evidence is available for the Western countries (Table A3) and the effect is even negative for the Eastern countries during pre-crisis period (Table A4). This result is in line with Meyer (2004) and Görg and Greenaway (2004), who show that a support for positive spillovers is not easy to find, and it contradicts some empirical studies that find a positive spillover effect of such backward linkages. Our explanation is that in reality, these studies do not disentangle properly the different channels of the influence of FDI and take for a positive technological transfer what may be simply an effect of increasing demand due to the activity of MNEs in the downstream sector.

The second channel through which downstream FDI affects the position of domestic suppliers of intermediary goods is the change in sourcing patterns, where these domestic firms are potentially replaced by MNEs entering the upstream industry. The interaction between downstream and upstream FDI $\left(\beta_{2}\right)$ should be negative - in such case the FDI in downstream industries attracts FDI to upstream industries, which then crowds-out domestic firms. This effect is clearly visible in our results and is consistent for both Western and Eastern countries, before and after the crisis, as well as for both types of estimation. The effect is particularly strong in the pre-crisis period.

The third channel through which downstream FDI affects the position of domestic suppliers of intermediary goods is a change in sourcing patterns resulting in a situation where domestic suppliers may be replaced by imports of upstream goods. This effect is captured by the interaction term between downstream FDI and upstream imports $\left(\beta_{4}\right)$, whose coefficient is indeed consistently negative for both types of estimation and is strongest in the pre-crisis period. Unfortunately, the effect is statistically significant only for Western countries in the modified estimation (Table A3). However, we believe that the loss of significance for the Eastern countries is purely due to inflated standard errors, since the magnitude of the coefficient is very similar for both groups. We can thus conclude that downstream FDI indeed attracts more imports of intermediary goods. However, the evidence of this mechanism being harmful for domestic producer is weaker than in case of attracted upstream FDI.

The fourth channel through which downstream FDI affects the position of domestic suppliers of intermediary goods are enhanced exports of these goods; the effect is captured by the interaction between downstream FDI and upstream exports $\left(\beta_{6}\right)$. The enhanced exports may be due to new trade channels that are opened thanks to the presence of MNEs in the country. Or they may be caused by a simple necessity to target new foreign markets when a domestic market shrinks after domestic producers are being crowded-out by MNEs and by importers. Our main estimation yields statistically insignificant coefficients (Tables 2 and 3 ). However, we do find statistically significant 
evidence of this effect for Western countries in our modified estimation (Table A3). Futher, for Eastern countries, we see a positive effect of similar magnitude, whose significance is undermined by inflated standard errors, though (Table A4).

The fifth and last channel through which downstream FDI affects the position of domestic suppliers of intermediary goods is that downstream FDI boosts production in the corresponding sector and more intermediary goods is demanded. Such scenario is based on two priors. First, the presence of MNEs in a sector boosts the production in this sector, and second, increased production in the downstream sector increases production in the upstream sector. The first premise is consistently confirmed by our results for both types of estimation (Tables 2, 3, A3, and A4), even though indirectly. We observe that the coefficient of the dummy indicating no-FDI-presence in the upstream sector $\left(\beta_{9}\right)$ is always negative. Negative coefficient means that production of domestic firms is higher in sectors where MNEs operate (not to mention that the production of these MNEs should be added here). This indicates that MNEs enter sectors in which there is a potential of larger sales. An important implication is that even if MNEs crowd out domestic producers, the overall sales in the sector increase. The second prior states that increased production in the downstream sector implies increased production in the upstream sector $\left(\beta_{7}\right)$. However, this prior is confirmed only for Eastern countries, for which the coefficient on downstream sales is positive (Tables 3 and A4).

Our results also shed light on the issue of export, or rather trade-related, spillovers. We show that increasing exports of upstream goods $\left(\beta_{5}\right)$ are linked to increased production of domestic suppliers of these goods when we consider the modified estimation (Tables A3 and A4), but not when we consider our main panel estimation (Tables 2 and 3). The difference hints that increased production of domestic suppliers of upstream goods is responsive to direct production-trade links within each country (Tables A3 and A4) rather than to a production-trade developments in a specific industry across countries (Tables 2 and 3). On other hand, across both country groups and types of estimation, we see a negative coefficient on upstream sales by foreign firms $\left(\beta_{8}\right)$ but positive coefficient on imports of these goods $\left(\beta_{3}\right)$. This indicates that domestic producers are in general competing with MNEs in their industry. However, imported goods seem to be rather complements - they may indicate an increased demand for the overall production of the sector that is covered both by domestic producers and by importers. The result may also explain why imports induced by downstream FDI are much less harmful than those attracted by the MNEs in the upstream sector.

\section{Results for downstream analysis}

In this section we present results of our complementary specification (3) described in Section 3.3. In the analysis of the downstream industry we study how the downstream industry is affected by FDI in the corresponding upstream industry. Similarly as in Section 5.1 we report results separately for Western and Eastern European countries based on two sets of estimates. In our key type of estimation, we interact countryindustry specific fixed effects (countries are assumed to behave as a common market 
within the specific industry); results are reported in Tables 4 and 5. In the Appendix (Tables A5 and A6) we report results based on a modified estimation (extension and robustness check) where individual countries from within Western or Eastern countries are assumed to behave as separate markets (separate industry and individual country fixed effects). Each table has three column sections (whole time period 2001-2013, precrisis and post-crisis periods). Coefficient's symbols and table numbers are included in the text whenever they ease access to interpretation of our results.

The important observation related to the results of the downstream analysis is that they are more heterogeneous with respect to the chosen time-period and estimation specification than results from the upstream analysis. This shows that the link between domestic firms in the downstream sectors and their multinational suppliers is more sensitive to overall economic situation. Further, in the downstream-to-upstream direction the markets seem to be more divided by national borders: vertical linkages differ more when we consider the industry as aggregated over several countries (Table s 4 and 5) as opposed to specific country-industry units (Tables A5 and A6).

We find a weak positive pure spillover effect $\left(\beta_{1}\right)$ in the post-crisis period in Eastern countries (Table 5 ). The result indicates that within a given country and industry, domestic firms may benefit in difficult times from multinational suppliers via increasing their own efficiency. However, given the negative sign of the coefficient on interaction between upstream and downstream FDI $\left(\beta_{2}\right)$, the positive pure spillover effect $\left(\beta_{1}\right)$ gets relativized in case the domestic downstream firms operate in sectors that are also characterized by increased FDI levels. This can be due to the fact that vertical interactions happen primarily between MNEs themselves. Interestingly, we see a very different pattern in Western countries, where, in the pre-crisis period, the coefficient on interaction between upstream and downstream FDI is significantly positive $\left(\beta_{2}\right.$; Table 4). This finding indicates that in developed markets and at least during economic stability, domestic firms manage to benefit from vertical interactions between MNEs.

Another interesting result is the impact of imports $\left(\beta_{3}\right)$, which should represent a competition factor. For Eastern countries, we do not observe such competition effect (Table 5), though. On the contrary, at least in the pre-crisis times, imports seem to be rather complementary to domestic production of downstream goods and this statement is not affected by the activity of MNEs $\left(\beta_{4}\right)$. For Western countries, the competition effect is more pronounced in a complementary estimation where industries are considered across countries and, in the pre-crisis period, the effect is even stronger for downstream industries with higher FDI presence ( $\beta_{4}$; Table A5). When we consider the industrycountry specific units, then the complementarity of imports appears as well even in Western countries (Table 4).

The competition effect of foreign sales within the industry $\left(\beta_{8}\right)$ is clearly negative across time periods, groups of countries, and types of estimation. On the other hand, the effect of upstream sales $\left(\beta_{7}\right)$ is inconclusive and mostly insignificant. The exception is the outcome of the country-industry specific estimation for Eastern countries, where we observe a very weak negative relation between upstream sales and sales of 
downstream domestic producers (Table 5).

The coefficient on downstream exports $\left(\beta_{5}\right)$ is overall positive; it is mostly statistically insignificant in the main estimation (Tables 5 and 5 ) but statistically significant in an alternative one (Tables A5 and A6). Positive coefficient is something we could expect since it captures at least partially the effect of growing demand for consumer goods. For Western countries, this positive effect gets more pronounced in the pre-crisis period (Tables 4 and A5) and weakens in the post-crisis period (Tables 5 and A6) if there are more MNEs in the upstream sector $\left(\beta_{6}\right)$. This finding indicates interesting vertical linkages: if firms have more interactions with MNEs in the supplying sector, exports contribute to increased sales of domestic firms during economic upturn and to decreased sales during recession. This may be due to the fact that upstream FDI is often accompanied by downstream FDI (as we have already shown in Section 5.1). In addition, MNEs in the downstream sector may be more competitive in exporting than domestic producers, especially when the overall economic situation is not favorable. In Eastern countries, where such competition is likely to be even fiercer for domestic producers, we see that upstream FDI $\left(\beta_{6}\right)$ reduces the positive effect of total exports on sales by domestic producers across both time periods, even though in most specifications, we fail to find this effect to be significant (Tables 5 and A6).

Finally, we should add that the coefficient of the dummy indicating no-FDI-presence in the downstream sector $\left(\beta_{9}\right)$ is always negative. Interpretation is similar as in the upstream analysis (Section 5.1): production of domestic firms is higher only in sectors where MNEs operate. Hence, MNEs enter the sectors in which there is potential of larger sales and even if they crowd out domestic producers, the overall sales of the sector increase. This result is not surprising because all considered sectors can be downstream or upstream. This means that all variables that characterize within-industry linkages should have the same influence in both upstream and downstream analyses.

\section{Conclusion}

In this paper we provide a comprehensive analysis of the impact of the MNEs and FDI on domestic firms. Our framework covers both upstream and downstream directions through which the impacts materialize. We build on the theoretical model of Markusen and Venables (1999) and modify it to better reflect reality and to capture international industrial linkages. Based on the model we identify five basic channels of the impact spillovers. We then analyze the impact of MNEs and FDI empirically. For that we build a unique and large database that covers 30 European countries and spans over the time period 2001 - 2013. Data come from the Amadeus, UN Comtrade and BACl sources and their combination provides an unprecedented detail enabling to effectively analyze production-trade linkages within our framework.

We do not find evidence for a pure spillover effect (at upstream level) when other channels are controlled for. This surprising result is due to the fact that, based on our rich data, we are able to disentangle properly different channels of the FDl's impact. On a more detailed level we show that MNE's presence via its FDI has a significant effect 
on domestic firms in the upstream sectors, both in terms of changing market structure and productivity improvements.

On other hand, we find evidence of the change in sourcing patterns in that MNEs entering the upstream industry replace domestic firms or domestic suppliers may be replaced by imports of upstream goods. Specifically, we show that because of higher productivity in sectors that host entering MNEs, the demand for intermediary goods rises, which is positive for suppliers of these goods. Unfortunately, the extent to which domestic suppliers benefit from this increased demand is limited by increased competition with other MNEs operating in the sector of intermediary goods, which are preferred by MNE's customers and substitute the domestic production. In countries of Eastern Europe, this substitution effect is further intensified by increased competition with importers. On the other hand, those domestic firms, that are able to withstand this double competition, receive additional benefits stemming from their interaction with downstream MNEs in form of productivity spillovers.

Further, we document existence of trade (export) spillovers for both upstream and downstream levels. We show that increasing exports of upstream goods are linked to increased production of domestic suppliers of these goods as well. The effect might materialize either because of the newly opened trade channels or because of the aim to target new foreign markets. In both cases the MNEs presence is behind the finding. Even in the latter case when a domestic market shrinks after domestic producers are being crowded-out by MNEs and by importers, and they are forced to reach abroad to sell their products.

Our key results are complemented by analysis at the downstream level. Here, we find a rather limited evidence of the positive pure spillover effect. But we do show that production of domestic firms is sensitive to the MNEs presence as it increases in sectors where MNEs operate. We also document that downstream FDI boosts production in the corresponding sector and as a result more intermediary goods is demanded. Despite the fact that MNEs purposefully enter sectors in which there is potential of larger sales, even if they crowd out domestic producers the overall sales of the sector increase.

We conclude that the presence of the MNEs and their FDI in Europe substantially impacts domestic firms. The impact is not always beneficial at first sight because MNEs presence often crowds-out domestic suppliers. However, the existence of positive production and trade spillovers is overwhelming.

\section{Acknowledgement: The research was supported by GAČR grant No. 15-15927S.}


Table 1: Descriptive statistics, Descriptive statistics of the variable FDI in the upstream and downstream sectors.

Panel A. Western countries

\begin{tabular}{|c|c|c|c|c|c|c|}
\hline \multirow{2}{*}{ Country } & \multicolumn{3}{|c|}{ Upstream sectors } & \multicolumn{3}{|c|}{ Downstream sectors } \\
\hline & mean & std. deviation & maximum & mean & std. deviation & maximum \\
\hline AT & 0.008 & 0.043 & 0.475 & 0.012 & 0.044 & 0.245 \\
\hline $\mathrm{BE}$ & 0.017 & 0.076 & 0.566 & 0.015 & 0.054 & 0.281 \\
\hline $\mathrm{CH}$ & 0 & 0.001 & 0.027 & 0 & 0.001 & 0.018 \\
\hline DE & 0.008 & 0.053 & 0.843 & 0.033 & 0.121 & 0.563 \\
\hline DK & 0.011 & 0.057 & 0.89 & 0.01 & 0.037 & 0.18 \\
\hline ES & 0.018 & 0.078 & 0.58 & 0.021 & 0.075 & 0.324 \\
\hline $\mathrm{FI}$ & 0.018 & 0.075 & 0.709 & 0.02 & 0.072 & 0.416 \\
\hline FR & 0.018 & 0.081 & 0.866 & 0.016 & 0.053 & 0.292 \\
\hline GB & 0.005 & 0.015 & 0.086 & 0.002 & 0.007 & 0.044 \\
\hline GR & 0.027 & 0.132 & 1 & 0.013 & 0.048 & 0.25 \\
\hline IE & 0.005 & 0.029 & 0.401 & 0.002 & 0.005 & 0.028 \\
\hline IS & 0.009 & 0.048 & 0.596 & 0.024 & 0.056 & 0.25 \\
\hline IT & 0.025 & 0.104 & 0.854 & 0.021 & 0.077 & 0.334 \\
\hline NL & 0 & 0 & 0.006 & 0.001 & 0.002 & 0.023 \\
\hline NO & 0.013 & 0.052 & 0.324 & 0.01 & 0.036 & 0.182 \\
\hline PT & 0.009 & 0.047 & 0.495 & 0.011 & 0.042 & 0.195 \\
\hline SE & 0.012 & 0.068 & 0.77 & 0.03 & 0.111 & 0.553 \\
\hline
\end{tabular}


Panel B. Eastern Countries

\begin{tabular}{|c|c|c|c|c|c|c|}
\hline \multirow{2}{*}{ Country } & \multicolumn{3}{|c|}{ Upstream sectors } & \multicolumn{3}{|c|}{ Downstream sectors } \\
\hline & mean & std. deviation & maximum & mean & std. deviation & maximum \\
\hline$B G$ & 0.057 & 0.191 & 0.959 & 0.054 & 0.166 & 0.748 \\
\hline CY & 0 & 0 & 0 & 0 & 0 & 0 \\
\hline $\mathrm{CZ}$ & 0.028 & 0.127 & 0.913 & 0.036 & 0.13 & 0.585 \\
\hline EE & 0.023 & 0.129 & 0.994 & 0.038 & 0.133 & 0.576 \\
\hline HR & 0.03 & 0.117 & 0.932 & 0.026 & 0.095 & 0.454 \\
\hline $\mathrm{HU}$ & 0.002 & 0.029 & 0.509 & 0.001 & 0.007 & 0.118 \\
\hline LT & 0.015 & 0.067 & 0.501 & 0.017 & 0.059 & 0.274 \\
\hline LV & 0.022 & 0.111 & 0.88 & 0.027 & 0.098 & 0.444 \\
\hline MT & 0 & 0 & 0 & 0 & 0 & 0 \\
\hline PL & 0.022 & 0.082 & 0.532 & 0.019 & 0.067 & 0.392 \\
\hline RO & 0.027 & 0.112 & 1 & 0.024 & 0.083 & 0.384 \\
\hline SI & 0.016 & 0.086 & 0.746 & 0.025 & 0.09 & 0.445 \\
\hline SK & 0.031 & 0.145 & 0.999 & 0.024 & 0.09 & 0.486 \\
\hline
\end{tabular}


Table 2: Sourcing effects of FDI activity: Upstream sector, Western countries. Interacting country and industry fixed effects.

\begin{tabular}{|c|c|c|c|c|c|c|c|}
\hline \multirow[b]{2}{*}{ FDIDown } & \multirow{2}{*}{$\begin{array}{c}\text { Coefficient } \\
\beta_{1}\end{array}$} & \multicolumn{2}{|c|}{ All years } & \multicolumn{2}{|c|}{ 2001-2008 } & \multicolumn{2}{|c|}{ 2009-2013 } \\
\hline & & -0.162 & -0.112 & 0.718 & 0.882 & -0.333 & -0.243 \\
\hline & & $(0.575)$ & $(0.573)$ & (3.813) & $(3.786)$ & $(0.653)$ & $(0.705)$ \\
\hline \multirow[t]{2}{*}{$F D I^{U p} . F D I^{\text {Down }}$} & $\beta_{2}$ & $-1.449^{a}$ & $-1.474^{a}$ & $-37.375^{b}$ & $-40.235^{b}$ & $-1.598^{a}$ & $-1.579^{a}$ \\
\hline & & $(0.478)$ & $(0.480)$ & $(16.651)$ & $(17.527)$ & $(0.325)$ & $(0.307)$ \\
\hline \multirow[t]{2}{*}{$\ln \left(\operatorname{Imports}{ }^{U p}\right)$} & $\beta_{3}$ & $0.134^{b}$ & $0.134^{b}$ & 0.126 & 0.127 & $0.194^{a}$ & $0.197^{a}$ \\
\hline & & $(0.066)$ & $(0.066)$ & $(0.090)$ & $(0.090)$ & $(0.062)$ & $(0.062)$ \\
\hline \multirow[t]{2}{*}{$\ln \left(I m p o r t s^{U p}\right) . F D I^{\text {Down }}$} & $\beta_{4}$ & -0.036 & -0.042 & -0.391 & -0.398 & -0.012 & 0.003 \\
\hline & & $(0.147)$ & $(0.147)$ & $(0.339)$ & $(0.339)$ & $(0.148)$ & $(0.149)$ \\
\hline \multirow[t]{2}{*}{$\ln \left(\right.$ Exports $\left.^{U p}\right)$} & $\beta_{5}$ & 0.042 & 0.042 & 0.071 & 0.069 & -0.049 & -0.052 \\
\hline & & $(0.069)$ & $(0.069)$ & $(0.098)$ & $(0.097)$ & $(0.067)$ & $(0.068)$ \\
\hline \multirow[t]{2}{*}{$\ln \left(\text { Exports }^{U p}\right)^{c} F D I^{\text {Down }}$} & $\beta_{6}$ & 0.057 & 0.060 & 0.365 & 0.361 & 0.042 & 0.022 \\
\hline & & $(0.139)$ & $(0.139)$ & $(0.372)$ & $(0.374)$ & $(0.147)$ & $(0.149)$ \\
\hline \multirow[t]{2}{*}{$\ln \left(\right.$ Sales $\left.^{\text {Down }}\right)$} & $\beta_{7}$ & $-0.054^{b}$ & $-0.053^{b}$ & $-0.077^{b}$ & $-0.075^{b}$ & -0.096 & -0.085 \\
\hline & & $(0.021)$ & $(0.022)$ & $(0.031)$ & $(0.032)$ & $(0.073)$ & $(0.070)$ \\
\hline \multirow[t]{2}{*}{ In(FSales $\left.{ }^{U p}\right)$} & $\beta_{8}$ & $-0.061^{a}$ & $-0.061^{a}$ & $-0.059^{a}$ & $-0.059^{a}$ & $-0.059^{b}$ & $-0.059^{b}$ \\
\hline & & $(0.015)$ & $(0.015)$ & $(0.016)$ & $(0.016)$ & $(0.025)$ & $(0.026)$ \\
\hline \multirow[t]{2}{*}{ noFDIUp } & $\beta_{9}$ & $-1.329^{a}$ & $-1.331^{a}$ & $-1.262^{\mathrm{a}}$ & $-1.254^{a}$ & $-1.291^{b}$ & $-1.302^{b}$ \\
\hline & & $(0.305)$ & $(0.304)$ & $(0.311)$ & $(0.313)$ & $(0.507)$ & $(0.513)$ \\
\hline \multirow[t]{2}{*}{$\ln \left(\right.$ Exports $\left.^{\text {Down }}\right)$} & $\beta_{10}$ & & 0.032 & & 0.051 & & 0.206 \\
\hline & & & $(0.063)$ & & $(0.136)$ & & $(0.384)$ \\
\hline
\end{tabular}




\begin{tabular}{|c|c|c|c|c|c|c|c|}
\hline \multirow[t]{2}{*}{ In (Imports $\left.{ }^{\text {Down }}\right)$} & \multicolumn{2}{|l|}{$\beta_{11}$} & -0.063 & & -0.145 & & $0.360^{c}$ \\
\hline & \multirow{3}{*}{$\beta_{0}$} & & $(0.066)$ & & $(0.122)$ & & $(0.218)$ \\
\hline \multirow[t]{2}{*}{ Constant } & & $22.486^{a}$ & $22.986^{a}$ & $22.747^{\mathrm{a}}$ & $24.284^{a}$ & $24.033^{\mathrm{a}}$ & $13.777^{\circ}$ \\
\hline & & $(0.898)$ & (1.140) & (1.198) & (1.764) & (2.102) & $(8.104)$ \\
\hline Country*Industry FE & & YES & YES & YES & YES & YES & YES \\
\hline Year FE & & YES & YES & YES & YES & YES & YES \\
\hline Within $\mathrm{R}^{2}$ & & 0.031 & 0.031 & 0.028 & 0.029 & 0.041 & 0.044 \\
\hline Between $\mathrm{R}^{2}$ & & 0.111 & 0.093 & 0.098 & 0.052 & 0.017 & 0.302 \\
\hline OverAll R² & & 0.092 & 0.077 & 0.086 & 0.046 & 0.013 & 0.258 \\
\hline N (observations) & & 5,903 & 5,903 & 3,780 & 3,780 & 2,123 & 2,123 \\
\hline
\end{tabular}

Note: The estimation is based on the specification (2), where we treated each country (within the group of Western countries) as a "separated", not fully integrated market. This approach means that we consider interaction between country and industry fixed effects.

${ }^{\mathrm{a}},{ }^{\mathrm{b}}$ and ${ }^{\mathrm{c}}$ denote significance at the $1 \%, 5 \%$, and $10 \%$ levels, respectively. Heteroscedasticity consistent standard errors are presented in parentheses. 
Table 3: Sourcing effects of FDI activity: Upstream sector, Eastern countries. Interacting country and industry fixed effects.

\begin{tabular}{|c|c|c|c|c|c|c|c|}
\hline \multirow[b]{2}{*}{ FDIDown } & \multirow{2}{*}{$\begin{array}{c}\text { Coefficient } \\
\beta_{1}\end{array}$} & \multicolumn{2}{|c|}{ All years } & \multicolumn{2}{|c|}{ 2001-2008 } & \multicolumn{2}{|c|}{ 2009-2013 } \\
\hline & & 0.014 & 0.030 & 2.424 & 2.531 & 0.149 & 0.208 \\
\hline & & $(0.368)$ & $(0.375)$ & $(9.846)$ & $(9.878)$ & $(0.395)$ & $(0.423)$ \\
\hline \multirow[t]{2}{*}{$F D I^{U p ~ c} F D I^{\text {Down }}$} & $\beta_{2}$ & $-0.136^{a}$ & $-0.137^{a}$ & $-4.064^{a}$ & $-4.087^{a}$ & $-0.129^{a}$ & $-0.138^{a}$ \\
\hline & & $(0.022)$ & $(0.023)$ & $(1.120)$ & $(1.181)$ & $(0.023)$ & $(0.023)$ \\
\hline \multirow[t]{2}{*}{$\ln \left(I m p o r t s^{U p}\right)$} & $\beta_{3}$ & $0.284^{a}$ & $0.284^{a}$ & $0.312^{\mathrm{a}}$ & $0.312^{\mathrm{a}}$ & $0.247^{b}$ & $0.237^{b}$ \\
\hline & & $(0.088)$ & $(0.088)$ & $(0.095)$ & $(0.096)$ & $(0.110)$ & $(0.110)$ \\
\hline \multirow[t]{2}{*}{ In(Imports Up)c FDIDown } & $\beta_{4}$ & -0.023 & -0.022 & -1.342 & -1.335 & -0.001 & -0.009 \\
\hline & & $(0.059)$ & $(0.059)$ & $(1.646)$ & $(1.645)$ & $(0.059)$ & $(0.060)$ \\
\hline \multirow[t]{2}{*}{$\ln \left(\right.$ Exports $\left.^{U p}\right)$} & $\beta_{5}$ & 0.052 & 0.051 & 0.031 & 0.031 & 0.105 & 0.118 \\
\hline & & $(0.074)$ & $(0.075)$ & $(0.087)$ & $(0.087)$ & $(0.095)$ & $(0.094)$ \\
\hline \multirow[t]{2}{*}{$\operatorname{In}\left(\text { Exports }^{U p}\right)^{c} F D^{\text {Down }}$} & $\beta_{6}$ & 0.030 & 0.028 & 1.288 & 1.257 & -0.002 & 0.002 \\
\hline & & $(0.051)$ & $(0.050)$ & $(2.388)$ & $(2.390)$ & $(0.051)$ & $(0.051)$ \\
\hline \multirow[t]{2}{*}{$\ln \left(\right.$ Sales $\left.^{\text {Down }}\right)$} & $\beta_{7}$ & 0.061 & 0.062 & $0.128^{c}$ & $0.129^{c}$ & -0.054 & -0.033 \\
\hline & & $(0.055)$ & $(0.056)$ & $(0.068)$ & $(0.069)$ & $(0.113)$ & $(0.111)$ \\
\hline \multirow[t]{2}{*}{$\ln \left(F_{\text {Sales }}^{U p}\right)$} & $\beta_{8}$ & $-0.061^{a}$ & $-0.062^{a}$ & $-0.069^{a}$ & $-0.069^{a}$ & $-0.041^{b}$ & $-0.041^{b}$ \\
\hline & & $(0.010)$ & $(0.010)$ & $(0.014)$ & $(0.014)$ & $(0.016)$ & $(0.016)$ \\
\hline \multirow[t]{2}{*}{ noFDIUp } & $\beta_{9}$ & $-0.994^{a}$ & $-0.997^{a}$ & $-1.115^{a}$ & $-1.113^{a}$ & $-0.627^{b}$ & $-0.641^{b}$ \\
\hline & & $(0.182)$ & $(0.182)$ & $(0.253)$ & $(0.253)$ & $(0.266)$ & $(0.280)$ \\
\hline \multirow[t]{2}{*}{$\operatorname{In}\left(\right.$ Exports $\left.^{\text {Down }}\right)$} & $\beta_{10}$ & & 0.019 & & -0.061 & & $0.764^{c}$ \\
\hline & & & $(0.072)$ & & $(0.102)$ & & (0.394) \\
\hline
\end{tabular}




\begin{tabular}{|c|c|c|c|c|c|c|c|}
\hline In(Imports $\left.{ }^{\text {Down }}\right)$ & $\beta_{11}$ & & -0.040 & & 0.020 & & -0.360 \\
\hline \multirow{3}{*}{ Constant } & \multirow{3}{*}{$\beta_{0}$} & & $(0.089)$ & & $(0.122)$ & & $(0.364)$ \\
\hline & & $15.084^{a}$ & $15.377^{a}$ & $13.579^{a}$ & $14.133^{a}$ & $17.382^{a}$ & $10.760^{\circ}$ \\
\hline & & $(1.645)$ & $(1.520)$ & $(1.847)$ & $(1.980)$ & (3.188) & $(5.590)$ \\
\hline CountryIndustry FE & & YES & YES & YES & YES & YES & YES \\
\hline Year FE & & YES & YES & YES & YES & YES & YES \\
\hline Within $\mathrm{R}^{2}$ & & 0.043 & 0.043 & 0.051 & 0.051 & 0.049 & 0.055 \\
\hline Between $\mathrm{R}^{2}$ & & 0.222 & 0.219 & 0.235 & 0.227 & 0.157 & 0.213 \\
\hline OverAll $\mathrm{R}^{2}$ & & 0.207 & 0.205 & 0.226 & 0.221 & 0.154 & 0.203 \\
\hline N (observations) & & 4018 & 4018 & 2591 & 2591 & 1427 & 1427 \\
\hline
\end{tabular}

Note: The estimation is based on the specification (2), where we treated each country (within the group of Eastern countries) as a "separated", not fully integrated market. This approach means that we consider interaction between country and industry fixed effects.

${ }^{a},{ }^{b}$ and ${ }^{c}$ denote significance at the $1 \%, 5 \%$, and $10 \%$ levels, respectively. Heteroscedasticity consistent standard errors are presented in parentheses. 
Table 4: Sourcing effects of FDI activity: Downstream sector, Western countries. Interacting country and industry fixed effects.

\begin{tabular}{|c|c|c|c|c|c|c|c|}
\hline \multirow[b]{2}{*}{$F D / U p$} & \multirow{2}{*}{$\begin{array}{c}\text { Coefficient } \\
\beta_{1}\end{array}$} & \multicolumn{2}{|c|}{ All years } & \multicolumn{2}{|c|}{ 2001-2008 } & \multicolumn{2}{|c|}{ 2009-2013 } \\
\hline & & -0.673 & -0.690 & -4.691 & -4.878 & -0.743 & -0.776 \\
\hline & & $(0.560)$ & $(0.561)$ & $(8.494)$ & $(8.565)$ & $(0.734)$ & $(0.733)$ \\
\hline \multirow[t]{2}{*}{ FDIUp c FDIDown } & $\beta_{2}$ & $-1.504^{a}$ & $-1.512^{a}$ & -1.259 & -1.195 & $-1.374^{a}$ & $-1.362^{a}$ \\
\hline & & $(0.228)$ & $(0.227)$ & $(2.405)$ & $(2.440)$ & $(0.238)$ & $(0.242)$ \\
\hline \multirow{2}{*}{ In(Imports $\left.{ }^{\text {Down }}\right)$} & $\beta_{3}$ & 0.073 & 0.073 & $0.110^{\mathrm{b}}$ & $0.111^{\mathrm{b}}$ & 0.014 & 0.014 \\
\hline & & $(0.053)$ & $(0.053)$ & $(0.049)$ & $(0.049)$ & $(0.114)$ & $(0.114)$ \\
\hline \multirow[t]{2}{*}{$\ln \left(I m p o r t s^{\text {Down }}\right)^{c} F D / U p$} & $\beta_{4}$ & $0.208^{b}$ & $0.212^{\mathrm{b}}$ & -0.172 & -0.124 & 0.203 & 0.204 \\
\hline & & $(0.105)$ & $(0.105)$ & $(1.133)$ & $(1.140)$ & $(0.126)$ & $(0.127)$ \\
\hline \multirow[t]{2}{*}{$\ln \left(\right.$ Exports $\left.^{\text {Down }}\right)$} & $\beta_{5}$ & 0.080 & 0.080 & 0.048 & 0.047 & 0.130 & 0.130 \\
\hline & & $(0.063)$ & $(0.063)$ & $(0.052)$ & $(0.052)$ & $(0.137)$ & $(0.136)$ \\
\hline \multirow[t]{2}{*}{$\ln \left(\text { Exports }^{\text {Down }}\right)^{c} F D I^{U p}$} & $\beta_{6}$ & $-0.165^{c}$ & $-0.169 c$ & 0.823 & 0.811 & -0.165 & -0.163 \\
\hline & & $(0.092)$ & $(0.092)$ & $(0.829)$ & $(0.831)$ & $(0.113)$ & $(0.113)$ \\
\hline \multirow[t]{2}{*}{$\operatorname{In}\left(\right.$ Sales $\left.^{U p}\right)$} & $\beta_{7}$ & 0.006 & 0.006 & -0.004 & -0.008 & 0.005 & 0.003 \\
\hline & & $(0.022)$ & $(0.023)$ & $(0.032)$ & $(0.033)$ & $(0.069)$ & $(0.068)$ \\
\hline \multirow[t]{2}{*}{$\ln \left(\right.$ FSales $\left.^{\text {Down }}\right)$} & $\beta_{8}$ & $-0.057^{a}$ & $-0.057^{a}$ & $-0.064^{a}$ & $-0.064^{a}$ & $-0.059^{a}$ & $-0.060^{a}$ \\
\hline & & $(0.015)$ & $(0.015)$ & $(0.022)$ & $(0.022)$ & $(0.014)$ & $(0.014)$ \\
\hline \multirow[t]{2}{*}{ noFDIDown } & $\beta_{9}$ & $-1.250^{a}$ & $-1.252^{a}$ & $-1.401^{a}$ & $-1.401^{a}$ & $-1.258^{a}$ & $-1.265^{a}$ \\
\hline & & $(0.305)$ & $(0.305)$ & $(0.446)$ & $(0.445)$ & $(0.278)$ & $(0.280)$ \\
\hline \multirow[t]{2}{*}{$\ln \left(\right.$ Exports $\left.^{U p}\right)$} & $\beta_{10}$ & & -0.040 & & 0.101 & & -0.173 \\
\hline & & & $(0.072)$ & & $(0.162)$ & & $(0.271)$ \\
\hline
\end{tabular}




\begin{tabular}{|c|c|c|c|c|c|c|c|}
\hline \multirow[t]{2}{*}{ In(Imports $\left.{ }^{U p n}\right)$} & \multirow[t]{2}{*}{$\beta_{11}$} & & 0.046 & & -0.078 & & 0.244 \\
\hline & & & $(0.079)$ & & $(0.165)$ & & $(0.340)$ \\
\hline \multirow[t]{2}{*}{ Constant } & \multirow[t]{2}{*}{$\beta_{0}$} & $21.218^{\mathrm{a}}$ & $21.111^{\mathrm{a}}$ & $21.542^{\mathrm{a}}$ & $21.267^{\mathrm{a}}$ & $21.341^{\mathrm{a}}$ & $20.151^{\mathrm{a}}$ \\
\hline & & $(1.078)$ & $(1.226)$ & $(1.297)$ & (1.852) & (2.064) & (5.242) \\
\hline Country*Industry FE & & YES & YES & YES & YES & YES & YES \\
\hline Year FE & & YES & YES & YES & YES & YES & YES \\
\hline Within $\mathrm{R}^{2}$ & & 0.030 & 0.030 & 0.033 & 0.033 & 0.033 & 0.034 \\
\hline Between $\mathrm{R}^{2}$ & & 0.202 & 0.206 & 0.165 & 0.192 & 0.212 & 0.292 \\
\hline OverAll $\mathrm{R}^{2}$ & & 0.176 & 0.180 & 0.145 & 0.167 & 0.196 & 0.267 \\
\hline N (observations) & & 5,891 & 5,891 & 3,791 & 3,791 & 2,100 & 2,100 \\
\hline
\end{tabular}

Note: The estimation is based on the specification (3), where we treated each country (within the group of Western countries) as a "separated", not fully integrated market. This approach means that we consider interaction between country and industry fixed effects.

${ }^{\mathrm{a}},{ }^{\mathrm{b}}$ and ${ }^{\mathrm{c}}$ denote significance at the $1 \%, 5 \%$, and $10 \%$ levels, respectively. Heteroscedasticity consistent standard errors are presented in parentheses. 
Table 5: Sourcing effects of FDI activity: Downstream sector, Eastern countries. Interacting country and industry fixed effects.

\begin{tabular}{|c|c|c|c|c|c|c|c|}
\hline \multirow[b]{2}{*}{$F D I^{U p}$} & \multirow{2}{*}{$\begin{array}{c}\text { Coefficient } \\
\beta_{1}\end{array}$} & \multicolumn{2}{|c|}{ All years } & \multicolumn{2}{|c|}{ 2001-2008 } & \multicolumn{2}{|c|}{ 2009-2013 } \\
\hline & & $0.680^{a}$ & $0.674^{\mathrm{a}}$ & 12.248 & 12.181 & $0.709^{a}$ & $0.688^{a}$ \\
\hline \multirow{3}{*}{$F D I^{U p} c$ FDIDown } & \multirow{3}{*}{$\beta_{2}$} & $(0.218)$ & $(0.217)$ & $(9.333)$ & $(9.397)$ & $(0.266)$ & $(0.263)$ \\
\hline & & $-0.217^{a}$ & $-0.215^{a}$ & -1.295 & -0.750 & $-0.264^{a}$ & $-0.259^{a}$ \\
\hline & & $(0.059)$ & $(0.059)$ & $(8.675)$ & (8.939) & $(0.082)$ & $(0.082)$ \\
\hline \multirow[t]{2}{*}{ In(Imports $\left.{ }^{\text {Down }}\right)$} & \multirow[t]{2}{*}{$\beta_{3}$} & $0.172^{b}$ & $0.172^{b}$ & $0.226^{b}$ & $0.226^{b}$ & 0.067 & 0.065 \\
\hline & & $(0.082)$ & $(0.081)$ & $(0.091)$ & $(0.091)$ & $(0.120)$ & $(0.120)$ \\
\hline \multirow[t]{2}{*}{ In $\left(\text { Imports }{ }^{\text {Down }}\right)^{c} F D I^{U p}$} & \multirow[t]{2}{*}{$\beta_{4}$} & 0.012 & 0.011 & 1.493 & 1.519 & 0.054 & 0.052 \\
\hline & & $(0.055)$ & $(0.055)$ & $(1.212)$ & $(1.231)$ & $(0.074)$ & $(0.076)$ \\
\hline \multirow[t]{2}{*}{$\ln \left(\right.$ Exports $\left.^{\text {Down }}\right)$} & \multirow[t]{2}{*}{$\beta_{5}$} & $0.134^{c}$ & $0.135^{c}$ & 0.125 & 0.124 & 0.191 & 0.191 \\
\hline & & $(0.077)$ & $(0.077)$ & $(0.078)$ & $(0.078)$ & $(0.122)$ & $(0.122)$ \\
\hline \multirow[t]{2}{*}{$\ln \left(\text { Exports }^{\text {Down }}\right)^{c} F D I^{U p}$} & \multirow[t]{2}{*}{$\beta_{6}$} & -0.052 & -0.050 & -2.529 & $-2.569^{c}$ & -0.089 & -0.086 \\
\hline & & $(0.055)$ & $(0.055)$ & $(1.534)$ & $(1.541)$ & $(0.072)$ & $(0.074)$ \\
\hline \multirow[t]{2}{*}{$\ln \left(\right.$ Sales $\left.^{U p}\right)$} & \multirow[t]{2}{*}{$\beta_{7}$} & $-0.113^{c}$ & $-0.117^{c}$ & $-0.101^{c}$ & -0.101 & -0.137 & -0.157 \\
\hline & & $(0.061)$ & $(0.063)$ & $(0.061)$ & $(0.062)$ & $(0.166)$ & $(0.180)$ \\
\hline \multirow[t]{2}{*}{$\ln \left(\right.$ FSales $\left.^{\text {Down }}\right)$} & \multirow[t]{2}{*}{$\beta_{8}$} & $-0.063^{a}$ & $-0.063^{a}$ & $-0.073^{a}$ & $-0.073^{a}$ & -0.045 & -0.043 \\
\hline & & $(0.012)$ & $(0.012)$ & $(0.013)$ & $(0.013)$ & $(0.029)$ & $(0.030)$ \\
\hline \multirow[t]{2}{*}{ noFD/Down } & \multirow[t]{2}{*}{$\beta_{9}$} & $-1.084^{a}$ & $-1.092^{\mathrm{a}}$ & $-1.237^{a}$ & $-1.242^{a}$ & -0.819 & -0.793 \\
\hline & & $(0.217)$ & $(0.218)$ & $(0.231)$ & $(0.231)$ & $(0.511)$ & $(0.519)$ \\
\hline \multirow[t]{2}{*}{$\ln \left(\right.$ Exports $\left.^{U p}\right)$} & \multirow[t]{2}{*}{$\beta_{10}$} & & 0.084 & & -0.088 & & -0.314 \\
\hline & & & $(0.105)$ & & $(0.155)$ & & $(0.371)$ \\
\hline
\end{tabular}




\begin{tabular}{|c|c|c|c|c|c|c|c|}
\hline \multirow[t]{2}{*}{ In(Imports Upn) } & \multicolumn{2}{|l|}{$\beta_{11}$} & -0.025 & & 0.060 & & 0.317 \\
\hline & \multirow{3}{*}{$\beta_{0}$} & & $(0.111)$ & & $(0.157)$ & & $(0.498)$ \\
\hline \multirow[t]{2}{*}{ Constant } & & $19.418^{a}$ & $18.677^{\mathrm{a}}$ & $18.763^{a}$ & $19.155^{a}$ & $20.532^{a}$ & $20.812^{a}$ \\
\hline & & (1.908) & (1.917) & $(1.984)$ & (2.397) & $(4.416)$ & $(4.559)$ \\
\hline Country*Industry FE & & YES & YES & YES & YES & YES & YES \\
\hline Year FE & & YES & YES & YES & YES & YES & YES \\
\hline Within $\mathrm{R}^{2}$ & & 0.039 & 0.040 & 0.045 & 0.045 & 0.033 & 0.034 \\
\hline Between $\mathrm{R}^{2}$ & & 0.122 & 0.141 & 0.143 & 0.133 & 0.063 & 0.057 \\
\hline OverAll R² & & 0.129 & 0.142 & 0.152 & 0.146 & 0.081 & 0.076 \\
\hline N (observations) & & 4,003 & 4,003 & 2,572 & 2,572 & 1,431 & 1,431 \\
\hline
\end{tabular}

Note: The estimation is based on the specification (3), where we treated each country (within the group of Eastern countries) as a "separated", not fully integrated market. This approach means that we consider interaction between country and industry fixed effects.

${ }^{\mathrm{a}},{ }^{\mathrm{b}}$ and ${ }^{\mathrm{c}}$ denote significance at the $1 \%, 5 \%$, and $10 \%$ levels, respectively. Heteroscedasticity consistent standard errors are presented in parentheses. 


\section{Appendix}

Table A1. Definition of variables for upstream analysis

\begin{tabular}{|c|c|c|c|c|c|c|}
\hline $\begin{array}{l}0 \\
\text { s) } \\
\text { की }\end{array}$ & $\begin{array}{l}\frac{0}{7} \\
\frac{0}{0} \\
\frac{\pi}{2} \\
\frac{1}{4}\end{array}$ & $\begin{array}{l}\frac{0}{7} \\
\frac{0}{0} \\
\frac{\pi}{2} \\
\frac{\pi}{<}\end{array}$ & 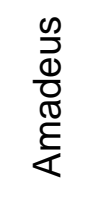 & 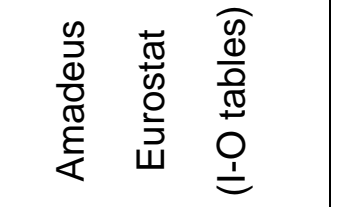 & $\begin{array}{l}\frac{\infty}{2} \\
\frac{0}{0} \\
\frac{\mathbb{0}}{\varepsilon} \\
\frac{\varepsilon}{<}\end{array}$ & 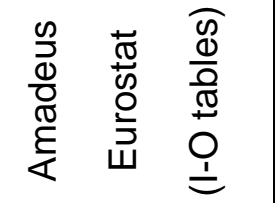 \\
\hline : & 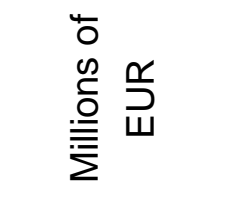 & 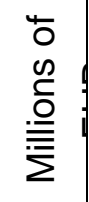 & 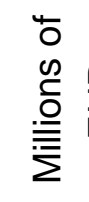 & 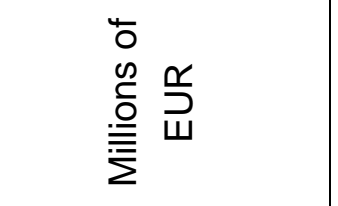 & 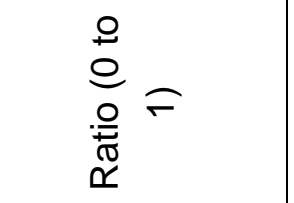 & 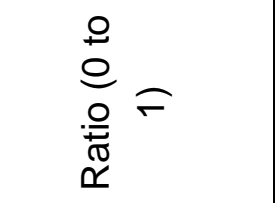 \\
\hline ㅎำ & 节 & 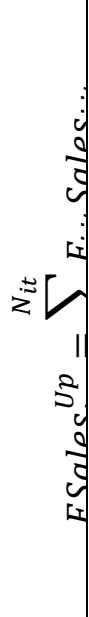 & 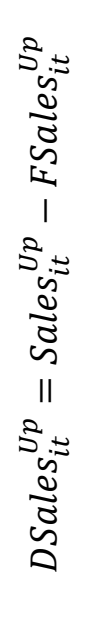 & 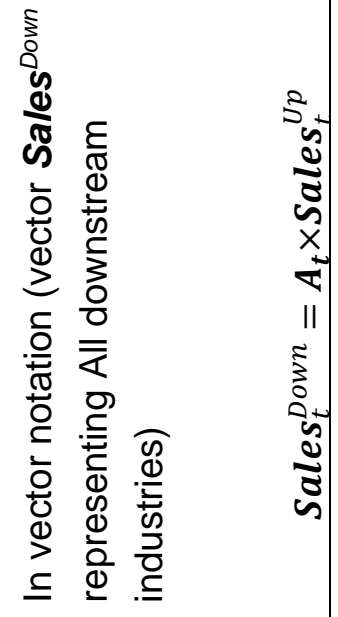 & 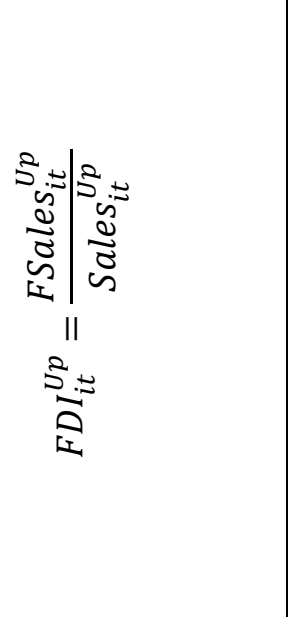 & 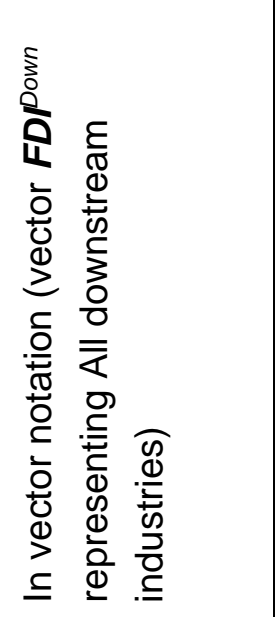 \\
\hline : & 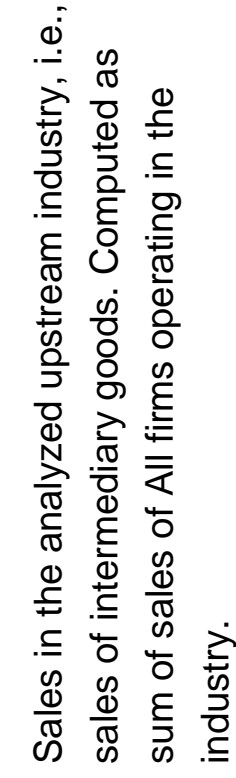 & 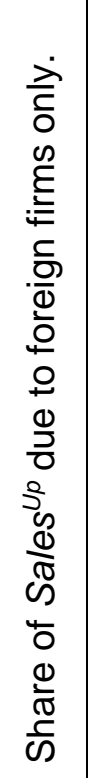 & 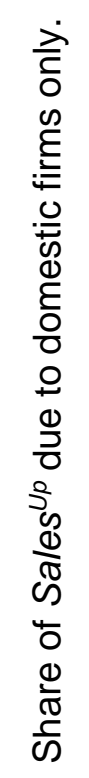 & 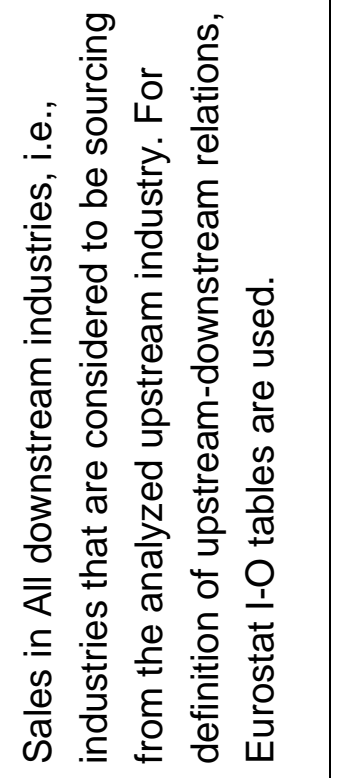 & 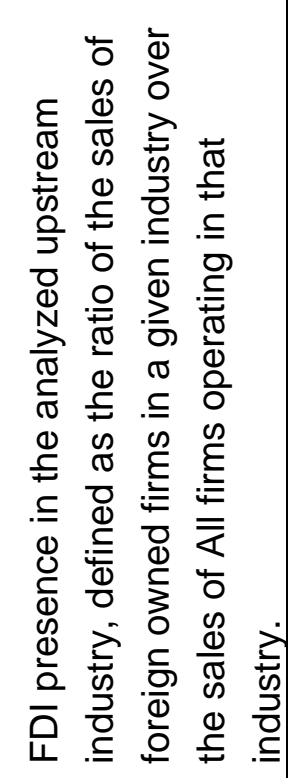 & 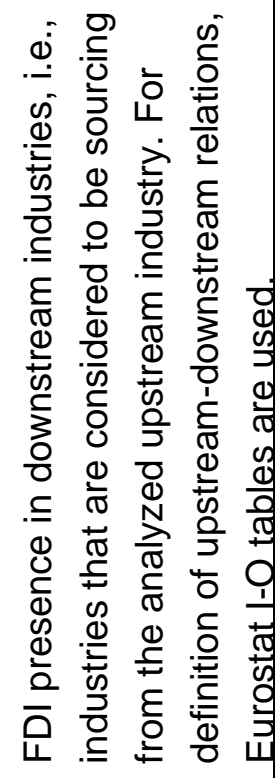 \\
\hline 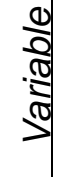 & $\begin{array}{l}\stackrel{2}{\infty} \\
\frac{\Phi}{\infty} \\
\omega\end{array}$ & 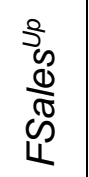 & 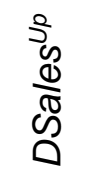 & 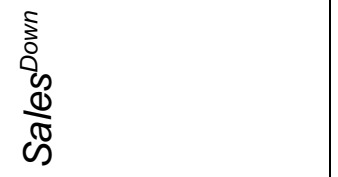 & $\frac{2}{2}$ & $\begin{array}{l}\frac{5}{0} \\
\frac{0}{0} \\
\frac{1}{4}\end{array}$ \\
\hline
\end{tabular}


Table A1. Definition of variables for upstream analysis (continued)

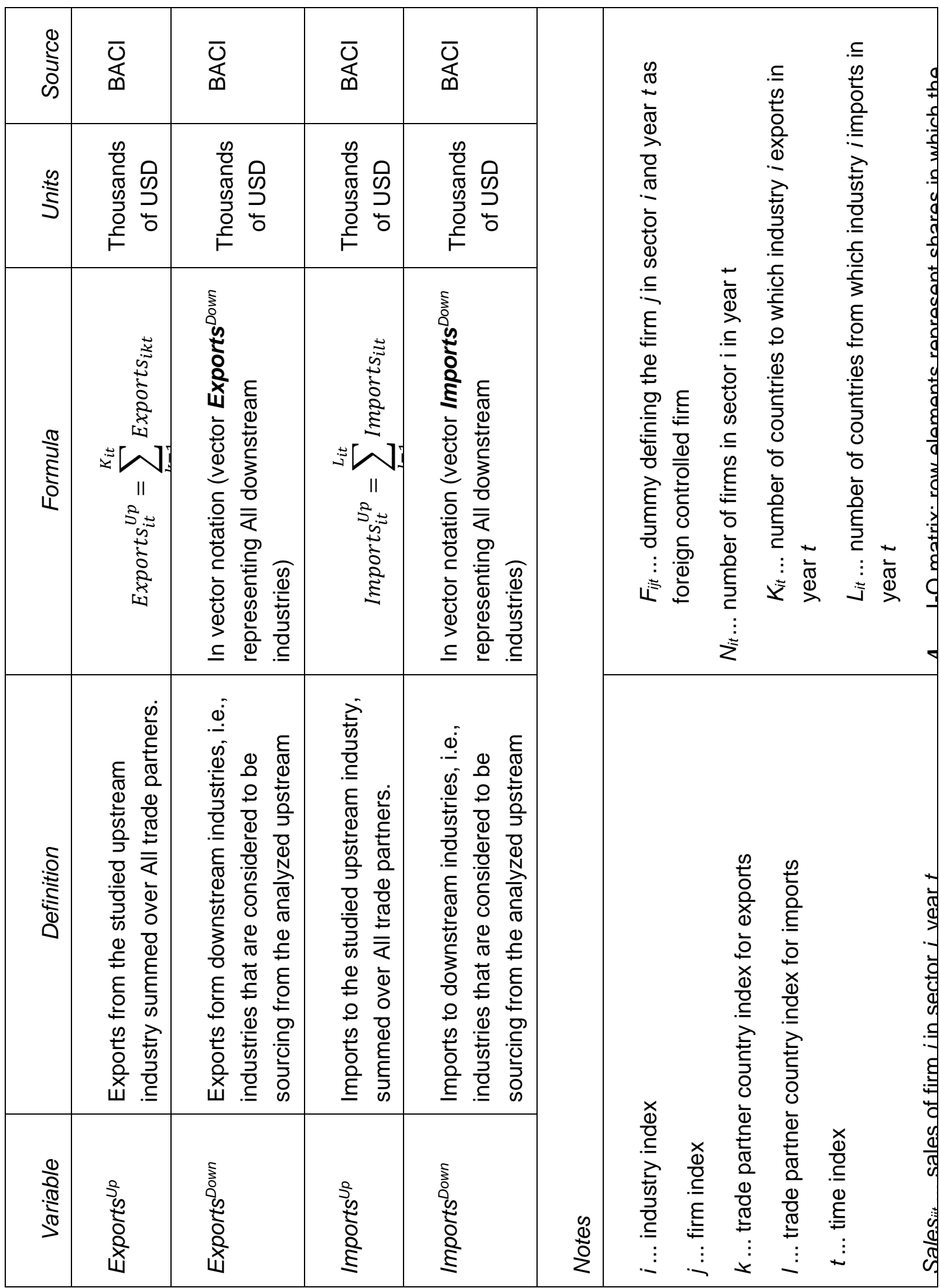


Table A2. Definition of variables for downstream analysis

\begin{tabular}{|c|c|c|c|c|c|c|}
\hline 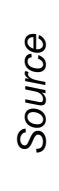 & $\begin{array}{l}\frac{\infty}{0} \\
\frac{0}{0} \\
\frac{\pi}{2} \\
\frac{1}{4}\end{array}$ & $\begin{array}{l}\frac{0}{0} \\
\frac{0}{0} \\
\frac{\pi}{2} \\
\frac{\varepsilon}{4}\end{array}$ & $\begin{array}{l}\frac{0}{0} \\
\frac{0}{0} \\
\stackrel{\mathbb{\pi}}{\frac{1}{\alpha}}\end{array}$ & 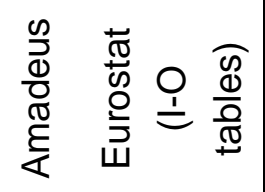 & $\begin{array}{l}\frac{0}{0} \\
\frac{0}{0} \\
\frac{\pi}{2} \\
\frac{\pi}{4}\end{array}$ & 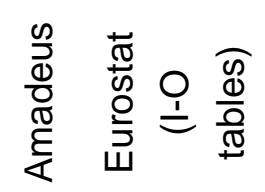 \\
\hline$\stackrel{n}{5}$ & 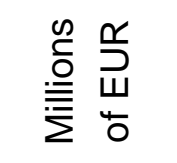 & 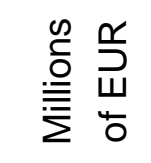 & 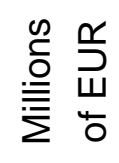 & 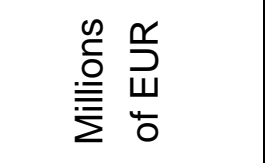 & 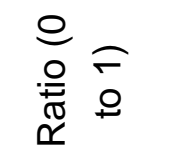 & 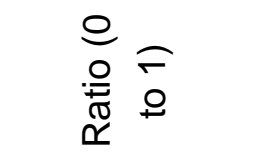 \\
\hline 난 & 节 & 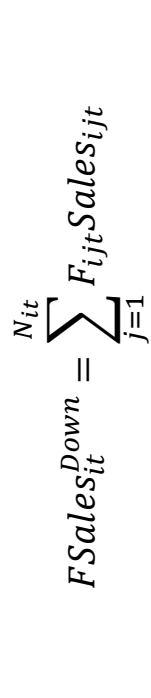 & 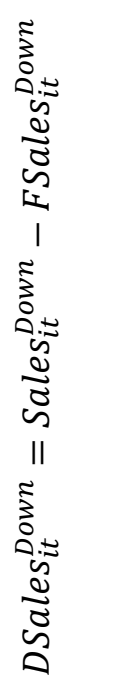 & 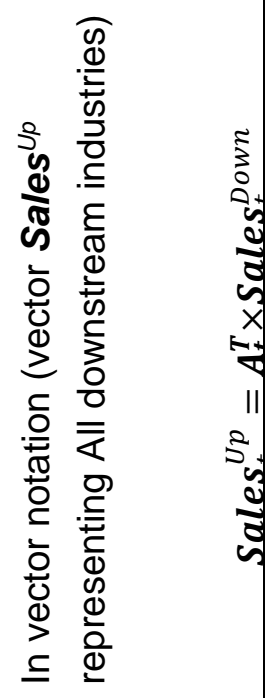 & 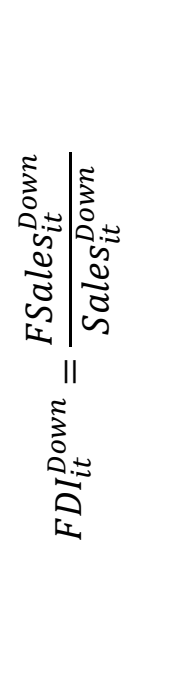 & 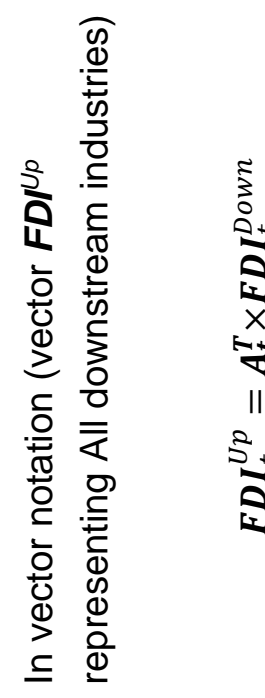 \\
\hline : & 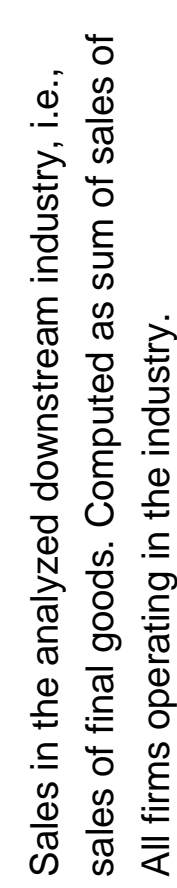 & 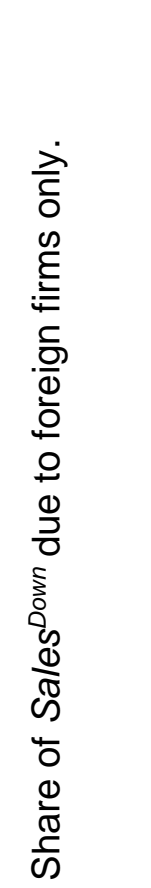 & 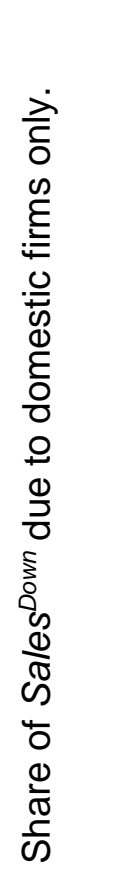 & 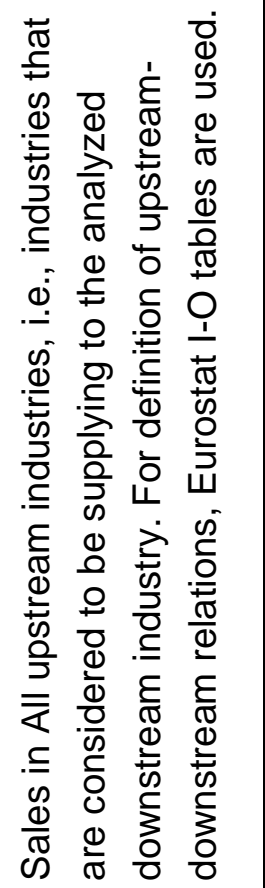 & 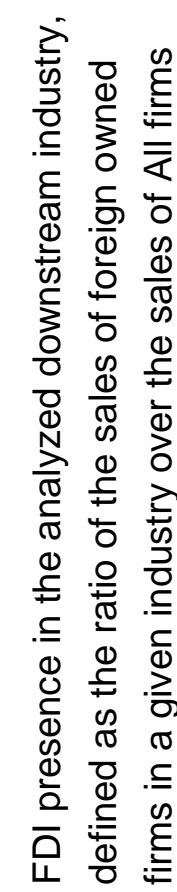 & 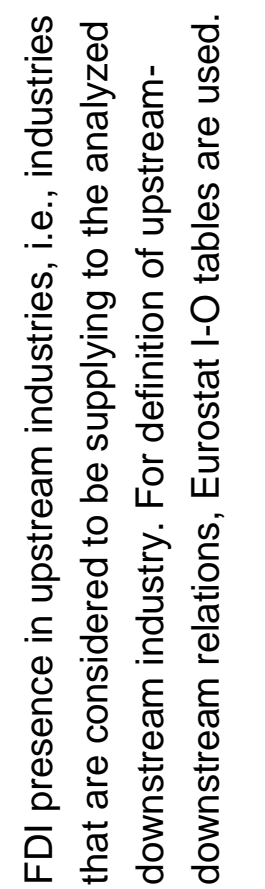 \\
\hline$\frac{\frac{0}{0}}{\frac{\pi}{2}}$ & 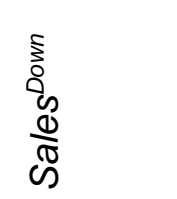 & 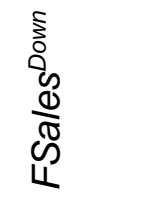 & 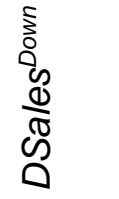 & $\begin{array}{l}\text { s. } \\
\frac{0}{10} \\
\text { की }\end{array}$ & $\begin{array}{l}\text { 音 } \\
\stackrel{0}{0} \\
\text { L }\end{array}$ & $\frac{2}{2}$ \\
\hline
\end{tabular}


Table A2. Definition of variables for downstream analysis (continued)

\begin{tabular}{|c|c|c|c|c|c|c|c|c|c|c|}
\hline $\begin{array}{l}0 \\
\vdots \\
\vdots \\
0\end{array}$ & ত্ণ & 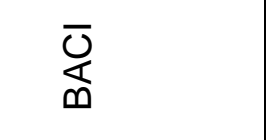 & 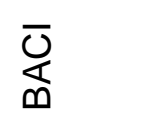 & $\begin{array}{l}\bar{\Phi} \\
\stackrel{\mathbb{\Phi}}{ }\end{array}$ & & \multirow{3}{*}{\multicolumn{2}{|c|}{ 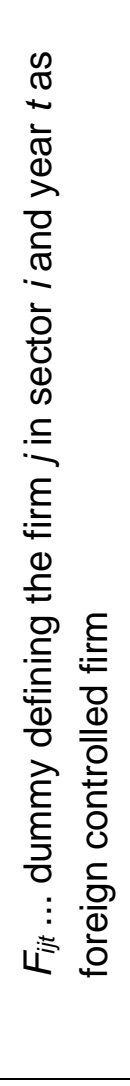 }} & \multirow[b]{3}{*}{ 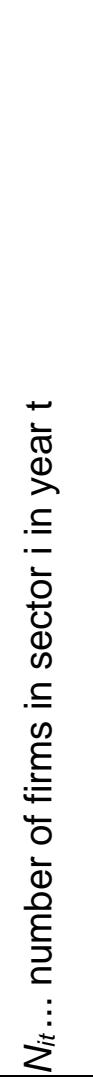 } & \multirow{3}{*}{ 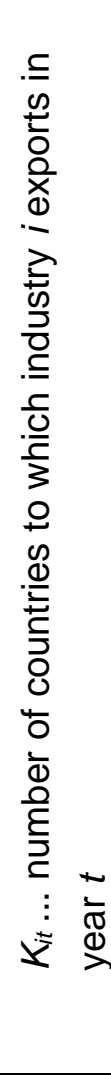 } & \multirow{3}{*}{ 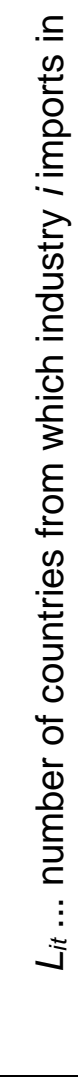 } \\
\hline$\frac{\text { D }}{\stackrel{5}{S}}$ & 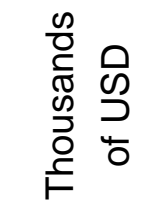 & 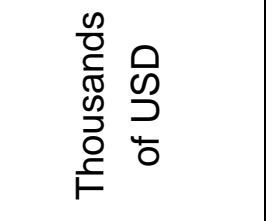 & 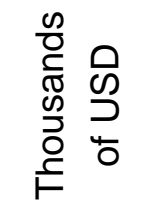 & 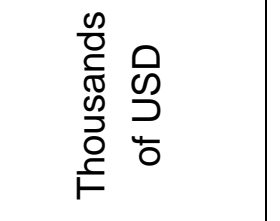 & & & & & & \\
\hline L & 苛 & 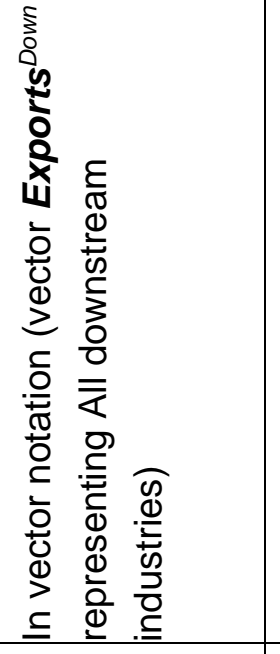 & 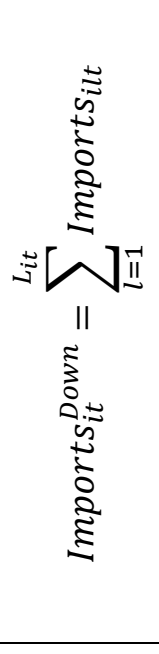 & 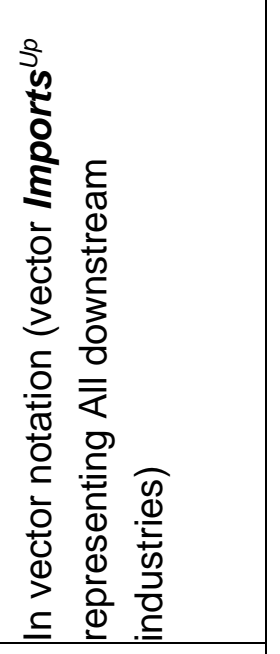 & & & & & & \\
\hline ר్ & 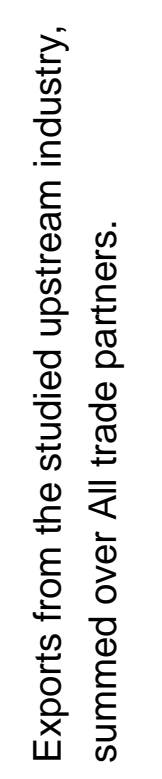 & 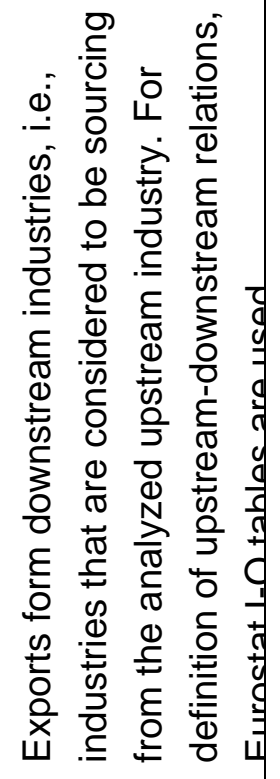 & 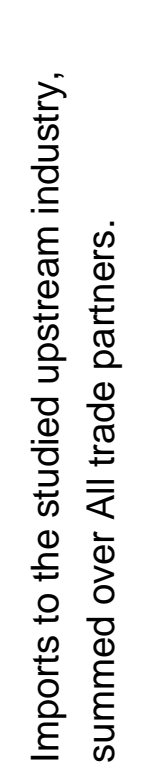 & 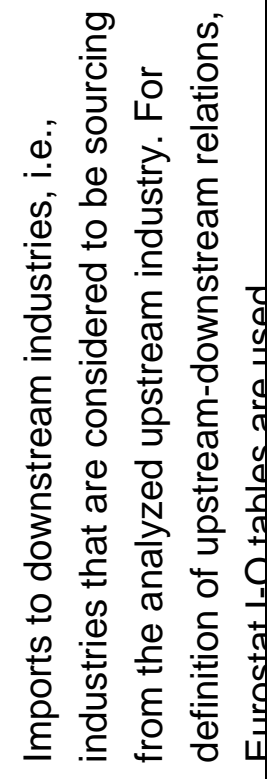 & $\frac{\mathscr{d}}{\stackrel{0}{0}}$ & $\underset{0}{0}$ & & 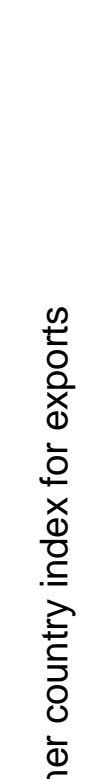 & 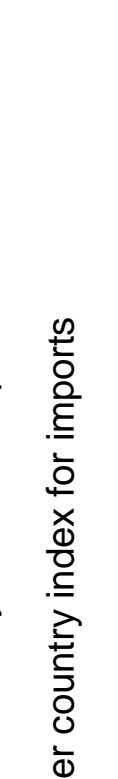 & \\
\hline $\begin{array}{c}\frac{0}{2} \\
\frac{0}{0} \\
\vdots \\
\vdots \\
0\end{array}$ & 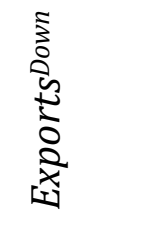 & $\begin{array}{l}5 \\
5 \\
0 \\
0 \\
0 \\
0 \\
0 \\
0\end{array}$ & 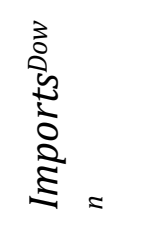 & \begin{tabular}{l}
5 \\
\multirow{2}{0}{} \\
0 \\
$\vdots$ \\
$\vdots$ \\
$\vdots$
\end{tabular} & & 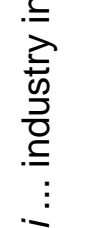 & 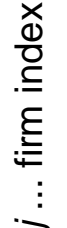 & 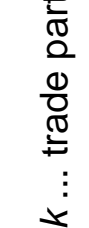 & 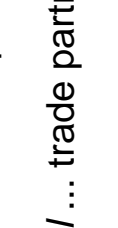 & 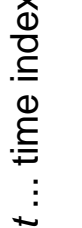 \\
\hline
\end{tabular}


Table A3: Sourcing effects of FDI activity: Upstream sector, Western countries. Separate country and industry fixed effects.

\begin{tabular}{|c|c|c|c|c|c|c|c|}
\hline \multirow[b]{2}{*}{ FDIDown } & \multirow{3}{*}{$\begin{array}{c}\text { Coefficient } \\
\beta_{1}\end{array}$} & \multicolumn{2}{|c|}{ All years } & \multicolumn{2}{|c|}{ 2001-2008 } & \multicolumn{2}{|c|}{$2009-2013$} \\
\hline & & -1.290 & -1.248 & -1.983 & -1.963 & -1.432 & -1.322 \\
\hline & & $(1.100)$ & $(1.096)$ & $(5.063)$ & $(5.000)$ & (1.192) & $(1.172)$ \\
\hline \multirow[t]{2}{*}{$F D I^{U p} \cdot F D I^{\text {Down }}$} & $\beta_{2}$ & $-1.722^{a}$ & $-1.704^{a}$ & -12.491 & -8.021 & $-1.845^{a}$ & $-1.912^{a}$ \\
\hline & & $(0.356)$ & $(0.353)$ & $(22.348)$ & $(23.140)$ & $(0.410)$ & $(0.401)$ \\
\hline \multirow[t]{2}{*}{$\ln (\operatorname{Imports} U p)$} & $\beta_{3}$ & $-0.052^{c}$ & $-0.047^{c}$ & -0.050 & -0.045 & -0.045 & -0.025 \\
\hline & & $(0.029)$ & $(0.028)$ & $(0.037)$ & $(0.036)$ & $(0.046)$ & $(0.045)$ \\
\hline \multirow[t]{2}{*}{ In(Imports Up).FDIDown } & $\beta_{4}$ & -0.068 & -0.050 & $-1.851^{a}$ & $-1.801^{a}$ & -0.020 & 0.018 \\
\hline & & $(0.203)$ & $(0.200)$ & $(0.638)$ & $(0.629)$ & $(0.194)$ & $(0.188)$ \\
\hline \multirow[t]{2}{*}{$\ln \left(\right.$ Exports $\left.^{U p}\right)$} & $\beta_{5}$ & $0.325^{\mathrm{a}}$ & $0.319^{a}$ & $0.327^{a}$ & $0.321^{a}$ & $0.310^{\mathrm{a}}$ & $0.290^{\mathrm{a}}$ \\
\hline & & $(0.022)$ & $(0.021)$ & $(0.027)$ & $(0.027)$ & $(0.035)$ & $(0.034)$ \\
\hline \multirow[t]{2}{*}{$\ln \left(E_{\text {xports }}^{U p}\right) . F D I^{\text {Down }}$} & $\beta_{6}$ & 0.160 & 0.143 & $2.262^{\mathrm{b}}$ & $2.244^{b}$ & 0.115 & 0.071 \\
\hline & & $(0.197)$ & $(0.195)$ & $(0.942)$ & $(0.940)$ & $(0.197)$ & (0.192) \\
\hline \multirow[t]{2}{*}{$\ln \left(\right.$ Sales $\left.^{\text {Down }}\right)$} & $\beta_{7}$ & -0.034 & $-0.053^{b}$ & $-0.071^{b}$ & $-0.086^{b}$ & -0.045 & -0.094 \\
\hline & & $(0.026)$ & $(0.026)$ & $(0.034)$ & $(0.034)$ & $(0.073)$ & $(0.071)$ \\
\hline \multirow[t]{2}{*}{$\ln \left(\right.$ FSales $\left.^{U p}\right)$} & $\beta_{8}$ & $-0.050^{a}$ & $-0.049^{a}$ & $-0.055^{a}$ & $-0.054^{a}$ & $-0.044^{b}$ & $-0.044^{b}$ \\
\hline & & $(0.012)$ & $(0.012)$ & $(0.016)$ & $(0.016)$ & $(0.021)$ & $(0.021)$ \\
\hline \multirow[t]{2}{*}{ noFDIUp } & $\beta_{9}$ & $-1.227^{a}$ & $-1.217^{a}$ & $-1.323^{a}$ & $-1.295^{a}$ & $-1.111^{a}$ & $-1.147^{a}$ \\
\hline & & $(0.245)$ & $(0.245)$ & $(0.316)$ & $(0.315)$ & $(0.405)$ & $(0.407)$ \\
\hline \multirow[t]{2}{*}{$\ln \left(\right.$ Exports $\left.^{\text {Down }}\right)$} & $\beta_{10}$ & & $0.169^{a}$ & & $0.154^{b}$ & & $0.377^{a}$ \\
\hline & & & $(0.046)$ & & $(0.069)$ & & $(0.076)$ \\
\hline
\end{tabular}




\begin{tabular}{|c|c|c|c|c|c|c|c|}
\hline \multirow[t]{2}{*}{ In(Imports $\left.{ }^{\text {Down }}\right)$} & \multicolumn{2}{|l|}{$\beta_{11}$} & -0.020 & & 0.011 & & $0.727^{a}$ \\
\hline & & & (0.064) & & $(0.117)$ & & $(0.175)$ \\
\hline \multirow[t]{2}{*}{ Constant } & $\beta_{0}$ & $19.441^{a}$ & $17.343^{a}$ & $20.327^{a}$ & $17.824^{\mathrm{a}}$ & $19.997^{a}$ & 1.232 \\
\hline & & $(0.785)$ & (1.265) & $(0.985)$ & (1.975) & (2.062) & (4.128) \\
\hline Country FE & & YES & YES & YES & YES & YES & YES \\
\hline Industry FE & & YES & YES & YES & YES & YES & YES \\
\hline Year FE & & YES & YES & YES & YES & YES & YES \\
\hline $\mathrm{R}^{2}$ & & 0.816 & 0.817 & 0.814 & 0.815 & 0.822 & 0.826 \\
\hline $\mathrm{N}$ & & 5,903 & 5,903 & 3,780 & 3,780 & 2,123 & 2,123 \\
\hline
\end{tabular}

Note: The estimation is based on the specification (2) where we treat the whole group of Western countries as an integrated market. This approach means that we consider separate fixed effects for country and industry.

${ }^{a},{ }^{b}$ and ${ }^{c}$ denote significance at the $1 \%, 5 \%$, and $10 \%$ levels, respectively. Heteroscedasticity consistent standard errors are presented in parentheses. 
Table A4: Sourcing effects of FDI activity: Upstream sector, Eastern countries. Separate country and industry fixed effects.

\begin{tabular}{|c|c|c|c|c|c|c|c|}
\hline \multirow[b]{2}{*}{ FDIDown } & \multirow{2}{*}{$\begin{array}{c}\text { Coefficient } \\
\beta_{1}\end{array}$} & \multicolumn{2}{|c|}{ All years } & \multicolumn{2}{|c|}{ 2001-2008 } & \multicolumn{2}{|c|}{ 2009-2013 } \\
\hline & & -0.462 & -0.462 & $-23.455^{b}$ & $-23.195^{c}$ & -0.570 & -0.520 \\
\hline \multirow{3}{*}{$F D I^{U p} . F D I^{\text {Down }}$} & \multirow{3}{*}{$\beta_{2}$} & $(0.561)$ & $(0.559)$ & (11.933) & $(12.036)$ & $(0.622)$ & $(0.620)$ \\
\hline & & $-0.105^{a}$ & $-0.109^{a}$ & $-4.848^{a}$ & $-4.704^{a}$ & $-0.139^{a}$ & $-0.149^{a}$ \\
\hline & & $(0.033)$ & $(0.033)$ & $(0.992)$ & $(1.027)$ & $(0.035)$ & $(0.035)$ \\
\hline \multirow[t]{2}{*}{$\ln \left(\right.$ Imports $\left.^{U p}\right)$} & \multirow[t]{2}{*}{$\beta_{3}$} & $0.176^{a}$ & $0.171^{\mathrm{a}}$ & $0.253^{a}$ & $0.249^{a}$ & 0.036 & 0.023 \\
\hline & & $(0.042)$ & $(0.043)$ & $(0.052)$ & $(0.053)$ & $(0.075)$ & $(0.075)$ \\
\hline \multirow[t]{2}{*}{ In(Imports $\left.{ }^{U p}\right) . F D I^{\text {Down }}$} & \multirow[t]{2}{*}{$\beta_{4}$} & -0.006 & -0.004 & -4.001 & -4.067 & 0.052 & 0.053 \\
\hline & & $(0.103)$ & $(0.103)$ & (3.555) & $(3.562)$ & $(0.112)$ & $(0.112)$ \\
\hline \multirow[t]{2}{*}{$\ln \left(\right.$ Exports $\left.^{U p}\right)$} & \multirow[t]{2}{*}{$\beta_{5}$} & $0.185^{a}$ & $0.187^{a}$ & $0.135^{\mathrm{a}}$ & $0.137^{a}$ & $0.288^{a}$ & $0.295^{a}$ \\
\hline & & $(0.030)$ & $(0.030)$ & $(0.038)$ & $(0.039)$ & $(0.052)$ & $(0.052)$ \\
\hline \multirow[t]{2}{*}{$\ln \left(\right.$ Exports $\left.^{U p}\right) . F D I^{\text {Down }}$} & \multirow[t]{2}{*}{$\beta_{6}$} & 0.054 & 0.051 & 6.408 & 6.510 & 0.012 & 0.007 \\
\hline & & $(0.086)$ & $(0.086)$ & (3.960) & (3.977) & $(0.093)$ & $(0.093)$ \\
\hline \multirow[t]{2}{*}{$\ln \left(\right.$ Sales $\left.^{\text {Down }}\right)$} & \multirow[t]{2}{*}{$\beta_{7}$} & $0.106^{c}$ & $0.102^{c}$ & $0.173^{b}$ & $0.171^{b}$ & 0.154 & 0.118 \\
\hline & & $(0.054)$ & $(0.056)$ & $(0.070)$ & $(0.072)$ & $(0.166)$ & $(0.189)$ \\
\hline \multirow[t]{2}{*}{$\ln \left(F^{\prime}\right.$ Sales $\left.{ }^{U p}\right)$} & \multirow[t]{2}{*}{$\beta_{8}$} & $-0.064^{a}$ & $-0.066^{a}$ & $-0.076^{a}$ & $-0.078^{a}$ & $-0.049^{b}$ & $-0.051^{b}$ \\
\hline & & $(0.011)$ & $(0.011)$ & $(0.013)$ & $(0.013)$ & $(0.020)$ & $(0.020)$ \\
\hline \multirow[t]{2}{*}{ noFDIUp } & \multirow[t]{2}{*}{$\beta_{9}$} & $-1.107^{a}$ & $-1.136^{a}$ & $-1.220^{a}$ & $-1.255^{a}$ & $-1.001^{a}$ & $-1.045^{a}$ \\
\hline & & $(0.194)$ & $(0.196)$ & $(0.233)$ & $(0.235)$ & $(0.359)$ & $(0.365)$ \\
\hline \multirow[t]{2}{*}{$\operatorname{In}\left(\right.$ Exports $\left.^{\text {Down }}\right)$} & \multirow[t]{2}{*}{$\beta_{10}$} & & $0.193^{c}$ & & 0.212 & & 0.383 \\
\hline & & & $(0.110)$ & & $(0.142)$ & & $(0.248)$ \\
\hline
\end{tabular}




\begin{tabular}{|c|c|c|c|c|c|c|c|}
\hline \multirow[t]{2}{*}{ In(Imports $\left.{ }^{\text {Down }}\right)$} & \multicolumn{2}{|c|}{$\beta_{11}$} & \multicolumn{2}{|l|}{-0.147} & \multicolumn{2}{|l|}{-0.162} & -0.269 \\
\hline & & & $(0.115)$ & & $(0.182)$ & & (0.199) \\
\hline \multirow[t]{2}{*}{ Constant } & $\beta_{0}$ & $12.126^{a}$ & $11.854^{\mathrm{a}}$ & $10.549^{a}$ & $10.224^{a}$ & $12.035^{\mathrm{a}}$ & $14.227^{\mathrm{a}}$ \\
\hline & & $(1.217)$ & (1.587) & (1.535) & (2.259) & (3.862) & (5.252) \\
\hline Country FE & & YES & YES & YES & YES & YES & YES \\
\hline Industry FE & & YES & YES & YES & YES & YES & YES \\
\hline Year FE & & YES & YES & YES & YES & YES & YES \\
\hline $\mathrm{R}^{2}$ & & 0.712 & 0.713 & 0.718 & 0.719 & 0.712 & 0.713 \\
\hline $\mathrm{N}$ & & 0.712 & 0.713 & 0.718 & 0.719 & 0.712 & 0.713 \\
\hline
\end{tabular}

Note: The estimation is based on the specification (2), where we treated the whole group of Eastern countries as an integrated market. This approach means that we consider separate fixed effects for country and industry.

${ }^{a},{ }^{b}$ and ${ }^{c}$ denote significance at the $1 \%, 5 \%$, and $10 \%$ levels, respectively. Heteroscedasticity consistent standard errors are presented in parentheses. 
Table A5: Sourcing effects of FDI activity: Downstream sector, Western countries. Separate country and industry fixed effects.

\begin{tabular}{|c|c|c|c|c|c|c|c|}
\hline \multirow[b]{2}{*}{$F D I^{U p}$} & \multirow{2}{*}{$\begin{array}{c}\text { Coefficient } \\
\beta_{1}\end{array}$} & \multicolumn{2}{|c|}{ All years } & \multicolumn{2}{|c|}{ 2001-2008 } & \multicolumn{2}{|c|}{ 2009-2013 } \\
\hline & & -1.152 & -1.061 & 11.512 & 11.512 & -1.340 & -1.184 \\
\hline & & $(0.947)$ & $(0.845)$ & $(8.134)$ & $(8.234)$ & $(1.025)$ & $(1.024)$ \\
\hline \multirow[t]{2}{*}{ FDIUp. FDIDown } & $\beta_{2}$ & $-1.783^{a}$ & $-1.781^{b}$ & $13.552^{\mathrm{a}}$ & $13.811^{a}$ & $-1.953^{a}$ & $-1.849^{a}$ \\
\hline & & $(0.431)$ & $(0.745)$ & $(4.618)$ & $(4.714)$ & $(0.336)$ & $(0.316)$ \\
\hline \multirow[t]{2}{*}{$\ln \left(\operatorname{Imports^{Down}}\right)$} & $\beta_{3}$ & $-0.055^{c}$ & $-0.056^{a}$ & -0.039 & -0.039 & -0.080 & -0.080 \\
\hline & & $(0.031)$ & $(0.020)$ & $(0.036)$ & $(0.036)$ & $(0.056)$ & $(0.055)$ \\
\hline \multirow[t]{2}{*}{ In(Imports $\left.{ }^{\text {Down }}\right) \cdot F D / U p$} & $\beta_{4}$ & 0.285 & $0.300^{c}$ & $-5.654^{a}$ & $-5.793^{a}$ & $0.396^{b}$ & $0.400^{\mathrm{b}}$ \\
\hline & & $(0.193)$ & $(0.169)$ & $(1.715)$ & $(1.732)$ & $(0.194)$ & $(0.191)$ \\
\hline \multirow[t]{2}{*}{$\ln \left(\right.$ Exports $\left.^{\text {Down }}\right)$} & $\beta_{5}$ & $0.346^{a}$ & $0.339^{a}$ & $0.323^{a}$ & $0.314^{\mathrm{a}}$ & $0.378^{a}$ & $0.367^{a}$ \\
\hline & & $(0.023)$ & $(0.015)$ & $(0.026)$ & $(0.026)$ & $(0.044)$ & $(0.043)$ \\
\hline \multirow[t]{2}{*}{$\ln \left(E^{x p o r t s}{ }^{D o w n}\right) . F D I^{U p}$} & $\beta_{6}$ & -0.217 & -0.235 & $5.169^{a}$ & $5.478^{a}$ & $-0.326^{c}$ & $-0.336^{c}$ \\
\hline & & $(0.191)$ & $(0.159)$ & $(1.809)$ & $(1.861)$ & $(0.194)$ & $(0.190)$ \\
\hline \multirow[t]{2}{*}{$\ln \left(\right.$ Sales $\left.^{U p}\right)$} & $\beta_{7}$ & 0.015 & -0.015 & 0.005 & -0.027 & 0.045 & -0.017 \\
\hline & & $(0.025)$ & $(0.024)$ & $(0.033)$ & $(0.033)$ & $(0.060)$ & $(0.061)$ \\
\hline \multirow[t]{2}{*}{ In(FSales $\left.{ }^{\text {Down }}\right)$} & $\beta_{8}$ & $-0.056^{a}$ & $-0.055^{a}$ & $-0.072^{a}$ & $-0.072^{a}$ & $-0.027^{c}$ & $-0.027^{c}$ \\
\hline & & $(0.011)$ & $(0.012)$ & $(0.015)$ & $(0.015)$ & $(0.016)$ & $(0.016)$ \\
\hline \multirow[t]{2}{*}{ noFDIDown } & $\beta_{9}$ & $-1.282^{\mathrm{a}}$ & $-1.268^{a}$ & $-1.577^{a}$ & $-1.576^{a}$ & $-0.720^{b}$ & $-0.699^{b}$ \\
\hline & & $(0.225)$ & $(0.225)$ & $(0.299)$ & $(0.292)$ & (0.319) & $(0.317)$ \\
\hline $\ln ($ Exports $U p)$ & $\beta_{10}$ & & $0.141^{a}$ & & $0.153^{c}$ & & 0.182 \\
\hline
\end{tabular}




\begin{tabular}{|c|c|c|c|c|c|c|c|}
\hline & & & $(0.051)$ & & (0.092) & & $(0.115)$ \\
\hline \multirow[t]{2}{*}{ In(Imports $\left.{ }^{U p n}\right)$} & \multicolumn{2}{|l|}{$\beta_{11}$} & 0.047 & & 0.125 & & $0.551^{a}$ \\
\hline & & & $(0.074)$ & & (0.145) & & $(0.208)$ \\
\hline \multirow[t]{2}{*}{ Constant } & $\beta_{0}$ & $17.865^{a}$ & $15.446^{a}$ & $18.420^{\mathrm{a}}$ & $14.531^{a}$ & $16.482^{\mathrm{a}}$ & 4.767 \\
\hline & & $(0.787)$ & (1.108) & (0.997) & (2.026) & (1.795) & (3.365) \\
\hline Country FE & & YES & YES & YES & YES & YES & YES \\
\hline Industry FE & & YES & YES & YES & YES & YES & YES \\
\hline Year FE & & YES & YES & YES & YES & YES & YES \\
\hline $\mathrm{R}^{2}$ & & 0.824 & 0.824 & 0.827 & 0.827 & 0.824 & 0.826 \\
\hline $\mathrm{N}$ & & 5891 & 5891 & 3791 & 3791 & 2100 & 2100 \\
\hline
\end{tabular}

Note: The estimation is based on the specification (3) where we treat the whole group of Western countries as an integrated market. This approach means that we consider separate fixed effects for country and industry.

$\mathrm{a},{ }^{\mathrm{b}}$ and ${ }^{\mathrm{c}}$ denote significance at the $1 \%, 5 \%$, and $10 \%$ levels, respectively. Heteroscedasticity consistent standard errors are presented in parentheses. 
Table A6: Sourcing effects of FDI activity: Downstream sector, Eastern countries. Separate country and industry fixed effects.

\begin{tabular}{|c|c|c|c|c|c|c|c|}
\hline \multirow[b]{2}{*}{$F D I^{U p}$} & \multirow[b]{2}{*}{$\beta_{1}$} & \multicolumn{2}{|c|}{ All years } & \multicolumn{2}{|c|}{ 2001-2008 } & \multicolumn{2}{|c|}{ 2009-2013 } \\
\hline & & 0.264 & 0.178 & -0.731 & -3.020 & 0.061 & -0.018 \\
\hline & & $(0.350)$ & $(0.342)$ & $(15.28)$ & $(15.34)$ & $(0.370)$ & $(0.348)$ \\
\hline \multirow[t]{2}{*}{ FDIUp c FDI Down } & $\beta_{2}$ & -0.173 & -0.184 & 20.100 & 18.175 & -0.230 & -0.243 \\
\hline & & $(0.171)$ & $(0.185)$ & $(27.43)$ & $(27.67)$ & $(0.181)$ & $(0.179)$ \\
\hline \multirow[t]{2}{*}{ In(Imports $\left.{ }^{\text {Down }}\right)$} & $\beta_{3}$ & $0.081^{b}$ & $0.085^{b}$ & $0.141^{a}$ & $0.145^{\mathrm{a}}$ & -0.042 & -0.027 \\
\hline & & $(0.040)$ & $(0.040)$ & $(0.049)$ & $(0.050)$ & $(0.066)$ & $(0.066)$ \\
\hline \multirow[t]{2}{*}{ In(Imports $\left.{ }^{D o w n}\right) . F D / U p$} & $\beta_{4}$ & 0.034 & 0.038 & -0.760 & -0.700 & 0.072 & 0.066 \\
\hline & & $(0.086)$ & $(0.085)$ & (3.294) & $(3.224)$ & $(0.088)$ & $(0.086)$ \\
\hline \multirow[t]{2}{*}{$\ln \left(\right.$ Exports $\left.^{\text {Down }}\right)$} & $\beta_{5}$ & $0.263^{a}$ & $0.253^{a}$ & $0.254^{\mathrm{a}}$ & $0.238^{a}$ & $0.285^{\mathrm{a}}$ & $0.280^{a}$ \\
\hline & & $(0.029)$ & $(0.028)$ & $(0.035)$ & $(0.035)$ & $(0.052)$ & $(0.051)$ \\
\hline \multirow[t]{2}{*}{$\ln \left(\right.$ Exports $\left.^{\text {Down }}\right) . F D / U p$} & $\beta_{6}$ & -0.041 & -0.039 & 0.788 & 0.894 & -0.057 & -0.046 \\
\hline & & $(0.083)$ & $(0.082)$ & (3.106) & (3.068) & $(0.087)$ & $(0.084)$ \\
\hline \multirow[t]{2}{*}{$\operatorname{In}\left(\right.$ Sales $\left.^{U p}\right)$} & $\beta_{7}$ & -0.036 & -0.071 & -0.026 & -0.068 & $0.318^{b}$ & 0.261 \\
\hline & & $(0.054)$ & $(0.056)$ & $(0.070)$ & $(0.072)$ & $(0.159)$ & $(0.159)$ \\
\hline \multirow[t]{2}{*}{$\ln \left(F_{S}\right.$ Sales $\left.{ }^{\text {Down }}\right)$} & $\beta_{8}$ & $-0.060^{a}$ & $-0.059^{a}$ & $-0.059^{a}$ & $-0.060^{a}$ & $-0.066^{b}$ & $-0.060^{b}$ \\
\hline & & $(0.014)$ & $(0.014)$ & $(0.016)$ & $(0.015)$ & $(0.027)$ & $(0.029)$ \\
\hline \multirow[t]{2}{*}{ noFDIDown } & $\beta_{9}$ & $-1.120^{a}$ & $-1.118^{a}$ & $-1.062^{a}$ & $-1.078^{a}$ & $-1.341^{a}$ & $-1.227^{b}$ \\
\hline & & $(0.243)$ & $(0.245)$ & $(0.279)$ & $(0.276)$ & $(0.483)$ & $(0.522)$ \\
\hline \multirow[t]{2}{*}{$\ln \left(\right.$ Exports $\left.^{U p}\right)$} & $\beta_{10}$ & & -0.066 & & -0.024 & & $-0.570^{a}$ \\
\hline & & & $(0.095)$ & & $(0.123)$ & & $(0.205)$ \\
\hline
\end{tabular}




\begin{tabular}{|c|c|c|c|c|c|c|c|}
\hline \multirow[t]{2}{*}{ In(Imports $\left.{ }^{U p n}\right)$} & \multicolumn{2}{|c|}{$\beta_{11}$} & $0.415^{\mathrm{a}}$ & & $0.452^{b}$ & & $0.930^{\mathrm{a}}$ \\
\hline & \multirow{3}{*}{$\beta_{0}$} & & $(0.120)$ & & $(0.183)$ & & $(0.264)$ \\
\hline \multirow[t]{2}{*}{ Constant } & & $15.472^{\mathrm{a}}$ & $11.615^{\mathrm{a}}$ & $18.554^{a}$ & $12.535^{\mathrm{a}}$ & $11.875^{\mathrm{a}}$ & 6.277 \\
\hline & & (1.198) & (1.434) & $(1.900)$ & (2.567) & (4.592) & (5.354) \\
\hline Country FE & & YES & YES & YES & YES & YES & YES \\
\hline Industry FE & & YES & YES & YES & YES & YES & YES \\
\hline Year FE & & YES & YES & YES & YES & YES & YES \\
\hline $\mathrm{R}^{2}$ & & 0.719 & 0.721 & 0.724 & 0.726 & 0.721 & 0.723 \\
\hline $\mathrm{N}$ & & 4003 & 4003 & 2572 & 2572 & 1431 & 1431 \\
\hline
\end{tabular}

Note: The estimation is based on the specification (3) where we treat the whole group of Eastern countries as an integrated market. This approach means that we consider separate fixed effects for country and industry.

${ }^{a},{ }^{b}$ and ${ }^{c}$ denote significance at the $1 \%, 5 \%$, and $10 \%$ levels, respectively. Heteroscedasticity consistent standard errors are presented in parentheses. 


\section{Reference}

AITKEN, B. J.; HANSON, G. H. and HARRISON, A. E. (1997) Spillovers, foreign investment, and export behavior. Journal of International Economics. 1997, Vol. 43, No. 1-2, s. 103-132.

AITKEN, B. J. and HARRISON, A. E. (1999) Do domestic firms benefit from direct foreign investment? Evidence from Venezuela. American Economic Review. 1999, Vol. 89, No. 3, s. 605-618.

BLALOCK, G. and GERTLER, P. J. (2008) Welfare gains from Foreign Direct Investment through technology transfer to local suppliers. Journal of International Economics. 2008, Vol. 74, No. 2, s. 402-421.

BODMAN, P. and LE, T. (2013) Assessing the roles that absorptive capacity and economic distance play in the foreign direct investment-productivity growth nexus. Applied Economics. 2013, Vol. 45, s. 1027-1039.

COHEN, S. D. (2007) Multinational corporations and foreign direct investment: avoiding simplicity, embracing complexity. OUP Catalogue.

COSTA, I. and FILIPPOV, S. (2008) Foreign-Owned Subsidiaries: a Neglected Nexus between Foreign Direct Investment, Industrial and Innovation Policies. Science and Public Policy. 2008, Vol. 35, No. 6, s. 379-390.

DRIES, L. and SWINNEN, J. F. (2004) Foreign direct investment, vertical integration, and local suppliers: evidence from the polish dairy sector. World development. 2004, Vol. 32, No. 9, s. 1525-1544.

DUNNING, J. H. and LUNDAN, S. M. (2008) Multinational Enterprises and the Global Economy. Edward Elgar Publishing, 2008 - Business \& Economics.

ETHIER, W. (1986). The multinational firm. Quarterly Journal of Economics. 1986, Vol. 10, No. 4, s. 805834.

FRENSCH, R. and GAUCAITE-WITTICH, V. (2009) Product variety and technical change. Journal of Development Economics. 2009, Vol. 88, No. 2, s. 242-257.

GAULIER, G. and ZIGNAGO, S. (2010) BACI: International Trade Database at the Product-Level. The 1994-2007 Version CEPII Working Paper, N²010-23.

GÖRG, H. and GREENAWAY, D. (2004) Much Ado about Nothing? Do Domestic Firms Really Benefit from Foreign Direct Investment? The World Bank Research Observer. 2004, Vol. 19, No. 2, s. 171197.

GÖRG, H. and STROBL, E. (2001) Multinational companies and productivity spillovers: A meta-analysis with a test for publication bias. Economic Journal. 2001, Vol. 111, No. 475, s. 723-739.

GORODNICHENKO, Y.; SVEJNAR, J. and TERRELL, K. (2015) Does Foreign Entry Spur Innovation? NBER WP No. 21514., National Bureau of Economic Research, Inc.

GREENAWAY, D.; SOUSA, N. and WAKELIN, K. (2004) Do domestic firms learn to export from multinationals? European Journal of Political Economy. 2004, Vol. 20, s. 1027-1043.

HANOUSEK, J.; KOČENDA, E. and MAUREL, M. (2011) Direct and indirect effects of FDI in emerging European markets: Survey and Meta-analysis. Economic Systems. 2011, Vol. 35, No. 3, s. 301322.

HANOUSEK, J.; KOČENDA, E. and SHAMSHUR, A. (2015) Corporate efficiency in Europe. Journal of Corporate Finance. 2015, Vol. 32, s. 24-40.

HAVRÁNEK, T. and IRŠOVÁ, Z. (2012) Survey Article: Publication Bias in the Literature on Foreign Direct Investment Spillovers. Journal of Development Studies. 2012, Vol. 48. No. 10, s. 1375-1396.

HELPMAN, E. (1984) Multinational corporations and trade structure. Review of Economic Studies. 1984, 
Vol. 92, No. 3, s. 451-471.

IMF (2013) German-Central European supply chain—cluster report, IMF Country Report No. 13/263, Washington, D.C., August 2013.

JAVORCIK, B. (2004) Does foreign direct investment increase the productivity of domestic firms? In search of spillovers through backward linkages. American Economic Association. 2004, Vol. 93, No. 3, s. 605-627.

JAVORCIK, B. and SPATAREANU, M. (2005) Disentangling FDI spillover effects: What do firm perception tell us? In T. H. Moran, E. G. and Blomstrom, M., editors, Does Foreign Direct Investment Promote Development? Washington: Institute for International Economics.

JAVORCIK, B. and SPATAREANU, M. (2009) Tough love: Do Czech suppliers learn from their relationships with multinationals? Scandinavian Journal of Economics. 2009, Vol. 111, No. 4, s. 811-833.

JINDRA, B.; GIROUD, A., and SCOTT-KENNEL, J. (2009) Subsidiary roles, vertical linkages and economic development: Lessons from transition economies. Journal of World Business. 2009, Vol. 44, No. 2, s. 167-179.

JONES, G. (2014) Business History and the Impact of MNEs on Host Economies, in Jean J. Boddewyn (ed.) Multidisciplinary Insights from New AIB Fellows (Research in Global Strategic Management, Volume 16) Emerald Group Publishing Limited, pp.177 - 198

JORDAAN, J. A. (2011) FDI, local sourcing, and supportive linkages with domestic suppliers: The case of Monterrey, Mexico. World Development. 2011, Vol. 39, No. 4, s. 620-632.

JURAJDA, S. and STANČíK, J. (2012) Foreign ownership and corporate performance: The Czech Republic at EU entry. Czech Journal of Economics and Finance (Finance a uver). 2012, Vol. 62. No. 4, s. 306-324.

KELLER, W. (2010) International trade, foreign direct investment, and technology spillovers. Handbook of the Economics of Innovation. 2010, Vol. 2, s. 793-829.

KOENIG, P.; MAYNERIS, F., and PONCET, S. (2010) Local export spillovers in France. European Economic Review. 2010, Vol. 54, No. 4, s. 622-641.

LA PORTA, R.; LOPEZ-DE-SILANES, F. and SHLEIFER, A. (1999) Corporate ownership around the world. Journal of Finance. 1999, Vol. 54, No. 2, s 471-517.

LANZ, R. and MIROUDOT, S. (2011) Intra-firm trade: Patterns, determinants and policy implications. Technical report, OECD Publishing.

LESHER, M. and MIROUDOT, S. (2008) FDI spillovers and their interrelationships with trade. OECD Trade Policy Working Papers 80, OECD Publishing.

MARKUSEN, J. and VENABLES, A. (1999) Foreign direct investment as a catalyst for industrial development. European Economic Review. 1999, Vol. 43, No. 2, s. 335-356.

MEYER, K. E. (2004) Perspectives on multinational enterprises in emerging economies. Journal of International Business Studies. 2004, Vol. 35, s. 259-276.

MEYER, K. E. and SINANI, E. (2009) When and where does foreign direct investment generate positive spillovers? A meta-analysis. Journal of International Business Studies. 2009, Vol. 40, No. 7, s. 1075-1094.

OECD (2008) OECD Benchmark definition of foreign direct investment: fourth edition. Paris: Organisation for Economic Co-operation and Development.

OECD (2013) Trade in Intermediate Goods and International Supply Chains in CEFTA. CEFTA Issues
Paper
No.
6.
OECD,
Paris.
Available
at 
http://www.oecd.org/investmentcompact/CEFTA\%20IP6_Trade\%20in\%20Intermediate_Web\%20 and\%20Print.pdf

OECD (2015) FDI in Figures; April 2015. OECD, Paris. Available at http://www.oecd.org/daf/inv/investment-policy/FDI-in-Figures-April-2015.pdf

PERETTO, P. F. (2002) Endogenous market structure and the growth and welfare effects of economic integration. Journal of International Economics. 2002, Vol. 60, s. 177-201.

RODRÍGUEZ-CLARE, A. (1996) Multinationals, linkages, and economic development. American Economic Review. Vol. 86, No. 4, s. 852-873.

SMEETS, R. (2008) Collecting the pieces of the FDI knowledge spillovers puzzle. Research Observer, International Bank for Reconstruction and Development.

STANČík J. (2010). FDI Spillovers in the Czech Republic: Takeovers vs. Greenfields, in Keereman F. and Szekely I. (Eds.), Five Years of an Enlarged EU - A Positive Sum Game, Springer, s. 35-59.

XU, X. and SHENG, Y. (2012) Productivity spillovers from Foreign Direct Investment: Firm-level evidence from China. World Development. 2012, Vol. 40, No, 1, s. 62-74.

UNCTAD (2001). World investment report 2001: Promoting linkages. Technical report, United Nations Conference on Tariffs and Trade.

UZAGALIEVA, A.; KOČENDA, E. and MENEZES, A., (2012) Technological Innovation in New European Union Markets. Emerging Markets Finance and Trade. 2012, Vol. 48, No. 5, s. 51-69. 